\title{
35. THOLEIITES, BASALTIC ANDESITES, AND ANDESITES FROM LEG 60 SITES: GEOCHEMISTRY, MINERALOGY, AND LOW PARTITION COEFFICIENT ELEMENTS ${ }^{1}$
}

\author{
H. Bougault, ${ }^{2}$ R. C. Maury, ${ }^{3}$ M. El Azzouzi, ${ }^{3}$ J.-L. Joron, ${ }^{4}$ J. Cotten,${ }^{3}$ and M. Treuil ${ }^{4}$
}

\begin{abstract}
This chapter presents major oxide and trace element determinations of igneous whole-rock compositions from sites drilled during Leg 60 and electron microprobe mineral and glass analyses of samples from Sites 454 and 458 . Interarc basin basalts from the Mariana Trough (Sites 454 and 456) are similar in all respects to depleted mid-ocean ridge basalts. Basaltic andesites and andesites from Site 458 (Mariana fore-arc region) are more depleted than mid-ocean ridge basalts and show different geochemical behavior for $\mathrm{Zr}-, \mathrm{Hf}$, and $\mathrm{Ti}$ when compared on an extended CoryellMasuda plot.
\end{abstract}

\section{INTRODUCTION}

Samples recovered during DSDP Leg 60 have been investigated for major element geochemistry, mineralogy, and trace element behavior. Major differences between Sites 454 to 456 (tholeiites) and Sites 458 to 459 (basaltic andesites and andesites) correspond to different geological settings. Sites 454 and 456 are located in the Mariana Trough, an interarc basin currently spreading between the Mariana arc and West Mariana Ridge. The basalts are Pliocene and Pleistocene in age. At Sites 458 and 459 we reached lower Oligocene to upper Eocene basement in the fore-arc region of the Mariana arc. The setting and lithologic character of the igneous recovery are described in detail in the site reports of this volume.

\section{THOLEIITES FROM SITE 454}

\section{Chemical Composition (major elements)}

Five magmatic units were distinguished by the shipboard party at Site 454 . In the present chapter, Unit I (massive aphyric basalts) is represented by three samples: 454-5-1, 454-5-3, and 454-5-4; Unit II (fragments of medium-grained basalt) by Sample 454-6,CC; Unit III (thin pillow basalt layers) by Samples 454-8-1 and 454-10-1; Unit IV (massive basalt flows) by Samples 454-11-1, 454-11-2, and 454-12-1; and Unit V (pillow fragments) by Sample 454-16-1. All these lavas are aphyric (with the exception of sample 454-5-4), and their composition is representative of magmatic liquids.

The analyses and C.I.P.W. norms given in Table 1 show a relatively narrow range of composition, all the lavas from Hole 454 being clearly basaltic. Calculating their norms with the assumption that $\mathrm{Fe}_{2} \mathrm{O}_{3}=1.50 \%$, they are either olivine-hypersthene normative (5 samples) or hypersthene-quartz normative (3 samples). The presence of an important percentage of normative

\footnotetext{
1 Initial Reports of the Deep Sea Drilling Project, Volume 60.

${ }_{3}$ Centre Océanologique de Bretagne, CNEXO, B.P. 337, 29273 Brest, Cedex, France.

${ }_{4}^{3}$ Université de Bretagne Occidentale, 20 avenue Le Gorgeu, 29279 Brest, Cedex, France.

${ }^{4}$ Laboratoire P. Suje, CNRS, CEN Saclay, B.P. N 2 2, 91190 Gif-Sur-Yvette, France.
}

quartz in the case of Sample 454-10-1 seems to be due to an analytical underestimation of $\mathrm{Na}_{2} \mathrm{O}$ and that of normative nepheline in Sample 454-5-3 to overestimation of $\mathrm{CaO}$. The porphyritic Sample 454-5-4, which contains several olivine phenocrysts, is noticeably enriched in $\mathrm{MgO}$ and depleted in $\mathrm{SiO}_{2}$ and $\mathrm{Al}_{2} \mathrm{O}_{3}$ with respect to the other samples. Apart from these variations, the silicasaturated or oversaturated norms, the low amounts of $\mathrm{K}_{2} \mathrm{O}(0.09-0.48 \%)$, the $\mathrm{TiO}_{2}$ values close to $1 \%$, and the variation of $\mathrm{FeO} / \mathrm{MgO}$ versus $\mathrm{SiO}_{2}$ indicate that the lavas from Hole 454 have clearly a tholeitic character and that they are typical of the MORB magmas group on the basis of major element geochemistry.

\section{Mineralogy}

From the petrographic point of view, two types of lavas from Site 454 can be distinguished: glassy samples containing only phenocrysts of olivine and minute octahedra of brown spinel (454-8-1, 454-16-1) and mediumto well-crystallized basalts with plagioclase, pyroxene, olivine, and magnetite in the matrix, and occasionally as phenocrysts.

\section{Spinel-Olivine-Glass Tholeiite (Sample 454-8-1)}

This sample contains $10 \%$ idiomorphic olivine phenocrysts and $0.1 \%$ brown spinel octahedra about $10 \mu \mathrm{m}$ in size, both of them dispersed in brown homogeneous fresh glass. Some olivine phenocrysts contain glassy inclusions up to $200 \mu \mathrm{m}$.

The spinels (Table 2) are relatively constant in composition, ranging from 43.8 to $50.5 \%$ of $(\mathrm{Mg}, \mathrm{Fe})$ $\mathrm{Cr}_{2} \mathrm{O}_{4}, 41.9$ to $47.4 \%$ of $(\mathrm{Mg}, \mathrm{Fe}) \mathrm{Al}_{2} \mathrm{O}_{4}$, and 6.1 to $9.0 \%$ of $(\mathrm{Mg}, \mathrm{Fe}) \mathrm{Fe}^{3}{ }_{2}^{+} \mathrm{O}_{4}$. Their $\mathrm{Mg} / \mathrm{Fe}^{2+}$ ratio is close to $2.2(2.07-2.42)$; thus magnesiochromite is the most important compositional end member of these spinels. Their frequent occurrence as idiomorphic inclusions in olivine phenocrysts proves that they represent the liquidus phase of the tholeiitic magmas from Site 454 .

The olivine compositions (Table 3 ), $\mathrm{Fo}_{89-91}$, are remarkably constant, without any compositional zoning detectable within the limits of precision of the microprobe. The temperatures of possible equilibrium of these compositions with that of the total rock as well as 
with that of the glassy matrix have been calculated using Leeman and Scheidegger's (1977) method: they vary in a somewhat irregular manner from $1300^{\circ} \mathrm{C}$ to $1100^{\circ} \mathrm{C}$; consequently the olivine phenocrysts cannot be considered entirely as products of equilibrium crystallization of the enclosing lavas.

Glasses. Their compositions and C.I.P.W. norms are given in Table 4. The homogeneity of the glassy matrix is fairly good; its composition is that of a quartznormative tholeiite and does not differ very much from that of the total rock (with the exception of $\mathrm{MgO}$, depleted in the glass); it is fairly similar to the composition of the most evolved basalts of Hole 454, which can thus be considered as derived from magmas close in composition to Sample 454-8-1 by fractionation of about $10 \%$ olivine phenocrysts.

The glassy inclusions in olivine (Table 4, analyses 18-20) show compositional gradients, with systematic increases of $\mathrm{SiO}_{2}$ and $\mathrm{Al}_{2} \mathrm{O}_{3}$, and decreases of $\mathrm{FeO}^{*}$ and $\mathrm{MgO}$ from their cores to their rims; this indicates that at the time of quenching, olivine was still crystallizing at the expense of its glassy inclusions, the composition of which is markedly depleted in $\mathrm{MgO}$.

\section{Plagioclase and Pyroxene-bearing Tholeiite (Sample 454-11-2)}

In the matrix of this sample, the plagioclase crystals range in composition from labradorite $\left(\mathrm{An}_{67}\right)$ to bytownite $\left(\mathrm{An}_{75}\right)$; a plagioclase phenocryst $(400 \mu \mathrm{m}$ in diameter) shows a normal-type zoning from $\mathrm{An}_{63}$ (core) to $\mathrm{An}_{50}$ (rim).

Some clinopyroxene analyses are presented in Table 5. In the $\mathrm{Ca}-\mathrm{Mg}-(\mathrm{Fe}+\mathrm{Mn})$ diagram, the phenocrysts lie near the augite/salite boundary, close to the diopside field; the composition of microlites is less calcic and more iron-rich (augite). These pyroxenes have high $\mathrm{Al}_{2} \mathrm{O}_{3}$ concentrations (4-7\%), and moderate $\mathrm{TiO}_{2}$ (1.2$1.6 \%$ ), such as many pyroxenes from MORB-type magmas (Muir and Tilley, 1964; Mevel et al., 1979).

\section{BASALTIC ANDESITES AND ANDESITES FROM SITE 458}

\section{Lithology}

The five lithologic units in Hole 458 are represented in the present chapter by 14 samples: Unit I (glassy to fine-grained pillowed lavas) by Samples 458-28-1, 45829-2, and 458-30-2; Unit II (massive flows or sills) by Samples 458-32-3, 458-33-2, 458-35-2, and 458-37-2; Unit III (glassy to fine-grained lavas) by Samples 45839-3 and 458-40-1; Unit IV (glassy to fine-grained, massive to pillowed lavas) by Samples 458-41-1, 458-43-1, and 458-44-1; Unit V (massive fine-grained lava) by Samples 458-47-1 and 458-48-1. The occurrence of a major discontinuity between Units III and IV has been proposed (see site report, this volume) on the basis of abrupt variations of magnetic inclination and rock composition, the plagioclase-free bronzite andesites characteristic of this site occurring only in Units I and III.

Petrographically, three kinds of lavas can be distinguished among the samples available to us: (1) porphy- ritic basaltic andesites and andesites, with clinopyroxene and/or plagioclase phenocrysts, plagioclase, pyroxene, magnetite, and glass in the matrix (Samples 458-28-1, 458-29-2, 458-30-2, 458-32-3, 458-37-2, 458-48-1); (2) aphyric, predominantly glassy to fairly crystallized basaltic andesites or andesites, with plagioclase, clinopyroxene and magnetite in the matrix (Samples 458-35-2, 458-39-3, 458-40-1, 458-41-1, 458-43-1, 458-47-2; (3) plagioclase-free andesite (Sample 458-44-1) containing bronzite phenocrysts, clinopyroxene microphenocrysts and microlites, and glass.

It is noteworthy that the single bronzite andesite sample found among those available to us does not belong to Units I or III, where such lavas are relatively common, but to Unit IV, which was overlooked initially. Its occurrence undercuts an important argument for the presence of a major discontinuity between Units III and IV-i.e., the restricted occurrence of bronzite andesites in the upper part of the Site 458 igneous pile.

\section{Chemical Composition (Major Elements)}

The analyses and norms of 14 samples from Site 458 are presented in Table 6 .

1) All these lavas are clearly of orogenic affinities (in contrast to Hole 454). Almost all of them are silicaoversaturated, the amount of normative quartz reaching more than $10 \%$. The $\mathrm{TiO}_{2}$ percentages are characteristically very low: about $0.3 \%$ in the three upper units and 0.5 to $1 \%$ in the lower ones. The $\mathrm{K}_{2} \mathrm{O}$ values, often higher than $1 \%$, are too high for anorogenic basic tholeiitic magmas; for similar $\mathrm{SiO}_{2}$ contents, the compositions are very different from that of Hole 454 lavas, which are MORB-type. Lavas from Site 458 can thus be considered mainly aphyric or subaphyric andesitic (sensu lato) rocks, a type rare in island arc magmatism.

2) If $\mathrm{SiO}_{2}$ values are taken into consideration, they define a relatively narrow compositional range (51$56 \%$ ); following current classifications of calc-alkaline series, lavas with $\mathrm{SiO}_{2}<53 \%$ can be called basaltic andesites, those with $\mathrm{SiO}_{2}>53 \%$, andesites.

3) Generally speaking, lavas from the different units are fairly similar; owing to the small number of available samples, it is difficult to distinguish these units one from another on the basis of major element geochemistry. It is noteworthy, however, that the $\mathrm{TiO}_{2}$ contents of the three upper units are distinctly lower than in lavas of the two others; this chemical difference supports the idea of a major discontinuity between Units III and IV.

4) The plagioclase-free bronzite andesite Sample 458-44-1 appears to be one of the most evolved lavas of the group $\left(\mathrm{SiO}_{2}=55.78 \%\right)$, but its chemical composition is in no way unusual and is almost identical to that of some plagioclase-bearing andesites (e.g., Sample 45833-2).

\section{Mineralogy}

\section{Bronzite Andesite (Sample 458-44-1)}

A thin section of this rock shows a few phenocrysts of orthopyroxene $(<1 \%)$ in a matrix containing $65 \%$ brown glass and $35 \%$ elongated laths of clinopyroxene. 
Some of the latter crystals reach a size of $100 \times 25 \mu \mathrm{m}$ and may be considered microphenocrysts, the smaller ones being microlites. This rock may be considered a member of the boninite group (Kuroda et al., 1978); it differs from the boninites already dredged from the Mariana arc slope (Dietrich et al., 1978) by its lower $\mathrm{MgO}$ content and by lack of olivine and clinoenstatite. Representative analyses of pyroxenes and glasses from Sample 458-44-1 are given in Tables 7 and 8; the pyroxenes have also been plotted on the $\mathrm{Ca}-\mathrm{Mg}-(\mathrm{Fe}+\mathrm{Mn})$ diagram in Figure 1.

Bronzite phenocrysts reach in thin section a size of 800 $\times 400 \mu \mathrm{m}$; their orthorhombic symmetry has been confirmed by X-rays. The composition of their cores is close to $\mathrm{Wo}_{3} \mathrm{En}_{84} \mathrm{Fs}_{13}$; their rims may be slightly more iron-rich (Table 7, analyses 26 to 31 ). They contain significant amounts of $\mathrm{Cr}_{2} \mathrm{O}_{3}$ (up to $0.7 \%$ ), and their $\mathrm{TiO}_{2}$ and $\mathrm{Al}_{2} \mathrm{O}_{3}$ contents are very small.

Problem of the ferroaugite phenocrysts. In an attempt to measure the transition metals content of the pyroxenes from Sample 458-44-1, 1 gram of these pyroxenes was separated from the total rock by density and magnetic sorting. Thirty grains of dark green clinopyroxene, up to $200 \mu \mathrm{m}$ in size, were recovered during this operation. Microprobe study proved that they are Ca-Fe-rich clinopyroxenes (Table 7, analyses 31-36). In the pyroxene classification diagram (Fig. 1) most of them lie in the ferroaugite field, near the ferrosilite/ hedenbergite-ferrohedenbergite boundary. They contain significant amounts of $\mathrm{Na}_{2} \mathrm{O}(0.8$ to $1 \%)$ and $\mathrm{MnO}$ $(0.7$ to $1 \%)$ and are poor in $\mathrm{TiO}_{2}$ and $\mathrm{Al}_{2} \mathrm{O}_{3}$. Although these crystals have not been observed in thin section and the small available weight of sample precludes further study, contamination of the oxides during sorting seems to be excluded. Furthermore, some Fe-Ca-rich clinopyroxenes, including ferroaugite, have been found in situ in the matrix of the sample; boninites contain relatively iron-rich clinopyroxenes (Kuroda et al., 1978). Obviously such a Fe-rich clinopyroxene cannot have crystallized in equilibrium with bronzite; the orthopyroxeneclinopyroxene geothermometry (Wood and Banno,
1973; Wells, 1977) gives unreasonable results $\left(650^{\circ} \mathrm{C}\right.$ $850^{\circ} \mathrm{C}$ ) for this pair. If the occurrence of $\mathrm{Ca}-\mathrm{Fe}$-rich clinopyroxene phenocrysts in other bronzite andesite samples from Site 458 is confirmed, it will be necessary to consider these minerals as coming from a late stage of crystallization of calc-alkaline magmas of the boninite family.

Microphenocrysts and microlites. Their composition is surprisingly variable: extremely magnesian pigeonite $\left(\mathrm{En}_{75-78}\right)$, augite, ferroaugite, subcalcic augite, and subcalcic ferroaugite have been found (Table 7 and Fig. 1). Strong compositional variations can be observed in individual microphenocrysts. Table 7 (analyses 37-42) presents three examples of these variations: a core of subcalcic ferroaugite with a rim of magnesian pigeonite, a core of magnesian pigeonite with a rim of augite, and a core of ferroaugite with a rim of subcalcic augite. The most calcic microphenocrysts and microlites (augite, ferroaugite) contain very high amounts of alumina, a peculiarity for which we have no explanation at present. Magnesian pigeonite and augite are the most abundant clinopyroxene varieties in the matrix.

The considerable compositional scatter of these pyroxenes is probably a result of their rapid crystallization in a heterogeneous liquid (see the following). Generally, the major trend (Fig. 1) is a progressive increase of $\mathrm{Ca}$ and $\mathrm{Fe}$ from bronzite phenocrysts to ferroaugite microlites and microphenocrysts, and eventually (at a later stage of magmatic evolution?) to the ferroaugite phenocrysts described earlier. It is compatible with the hypothesis of a progressive separation of bronzite phenocrysts (together with olivine?) from the initial liquid.

Glasses (Table 8). Their composition is dacitic and roughly similar to that of the perlitic dacite of the boninite group described by Kuroda et al., 1978, excepted for their high $\mathrm{Al}_{2} \mathrm{O}_{3}$ contents $(18 \%)$, which may represent secondary alteration. The glasses analyzed far from pyroxene microlites or microphenocrysts are fairly identical (Table 8, analyses 51-56). Compositional gradients can be observed in the vicinity of the pyroxenes (Table 8, analyses 55-59): $\mathrm{Si}$ and $\mathrm{Al}$ increase, $\mathrm{Fe}, \mathrm{Mg}$, and $\mathrm{Ca}$

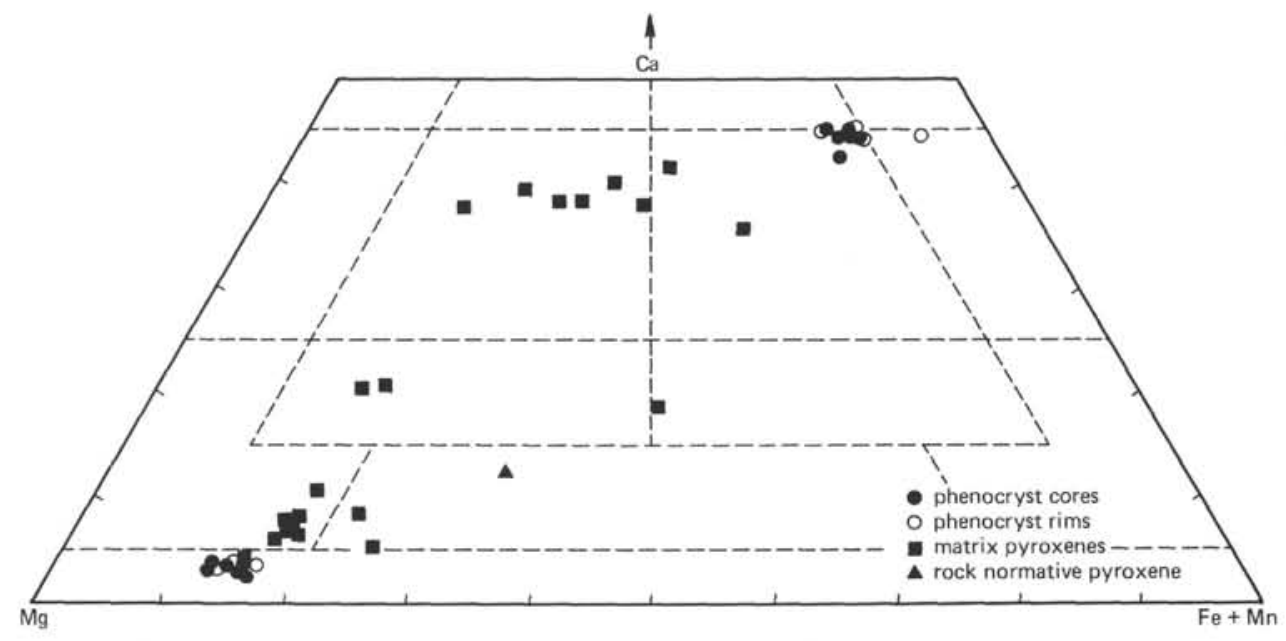

Figure 1. Hole 458: Sample 458-44-1, clinopyroxene composition from bronzite andesite. 
decrease toward the pyroxenes, indicating that the rate of crystallization of the pyroxenes was higher than the rate of diffusion in the surrounding liquids; near the pyroxenes, the glasses are thus depleted in the main components of these minerals, as predicted by Albarede and Bottinga (1972).

\section{Plagioclase-bearing Basaltic Andesites and Andesites}

Four samples of plagioclase-bearing and orthopyroxene-free andesites, 458-29-2 (Unit I), 458-33-2 and 458-37-2 (Unit II), and 458-47-1 (Unit V), have been investigated by microprobe. They range in composition from relatively basic basaltic andesites (Sample 45829-2, with $\mathrm{SiO}_{2}=51.54$ ) to andesites (Sample 454-33-2, with $\mathrm{SiO}_{2}=55.50$ ) chemically similar to the bronzite andesite sample described earlier.

Pyroxenes (Table 9 and Figure 2). The phenocrysts from Samples 458-29-2, 458-33-2, and 458-37-2 have a restricted range of composition, and most of them lie in the endiopside field near the endiopside/augite boundary. According to the composition of the total rock, the pyroxenes from Sample 458-47-1 are less magnesian and lie in the augite field as do most of the pyroxenes of orogenic magmas series. With respect to the phenocrysts, the microlites are enriched in iron, with or without corresponding decrease of their calcium contents; most of them lie in the augite field. Pyroxenes of endiopsidic compositions have been reported from a number of lavas, most of them located in orogenic series (Konda, 1970; Lowder, 1970; Ewart, 1976); their occurrence in MORB-type lavas seems to be less frequent (Wood et al., 1979a). The pyroxenes from plagioclasebearing lavas at Site 458 also have very low $\mathrm{TiO}_{2}$ content (mean value: $0.18 \%$ ), and their $\mathrm{Al}_{2} \mathrm{O}_{3}$ percentage is close to $22 \%$. These characteristics are in good agreement with the orogenic affinity of the surrounding lavas; indeed, Le Guen et al. (1979) have shown that pyroxenes from orogenic basic volcanic rocks contain less $\mathrm{TiO}_{2}$ and $\mathrm{Al}_{2} \mathrm{O}_{3}$ than those from ocean crust basalts; Nisbet and Pearce's (1977) diagrams also show differ- ences in $\mathrm{TiO}_{2}$ content between pyroxenes from these two types of lavas.

The compositions of plagioclases (Table 10) are labradorite or bytownite. The microlites are usually more calcic $\left(\mathrm{An}_{73-70}\right)$ than the phenocrysts, the zoning of which is predominantly normal.

\section{CHEMICAL COMPOSITION OF LAVAS FROM OTHER SITES (HOLES 456, 456A, AND 459B)}

The analyses of five lavas from Holes 456 and 456A and seven from Hole 459B are given in Table 11A. Major element composition of gabbros recovered in Hole 453 are given in Table 11B.

Lavas from Holes $456 \mathrm{~A}$ and 456 can be classified either as aphyric basalts with olivine, pyroxene, plagioclase, magnetite, and glass in the matrix (Samples 456A12-1 and 456-18-1) or as basalts containing some plagioclase phenocrysts, the matrix remaining identical to the former (Samples 456A-14-1, 456-16-2, and 456-19-1). All of these lavas are olivine-hypersthene normative, low in $\mathrm{K}_{2} \mathrm{O}(<0.4 \%)$, and moderately low in $\mathrm{TiO}_{2}$ (1.1-1.2\%). Their similarities with Hole 454 lavas are striking, and they can be related to a MORB-type magmatism.

Lavas from Hole 459B contain plagioclase, olivine, pyroxene, magnetite, and glass in their matrix; they are either aphyric (Samples 459B-60-2, 459B-61-2, 459B66-2, and 459B-72-1) or porphyritic with plagioclase, clinopyroxene, and olivine phenocrysts (Samples 459B60-1, 459B-69-1, and 459B-73-2). All of them are quartznormative, low in $\mathrm{TiO}_{2}(0.7-1.1 \%)$, and have a composition similar to that of basaltic andesites and andesites from Site 458 (orogenic magma type).

\section{LOW PARTITION COEFFICIENT ELEMENT: $\mathrm{Nb} / \mathrm{Ta}, \mathrm{Zr} / \mathrm{Hf}$, AND Y/Tb RATIOS}

Concentrations of these elements related to the first $(\mathrm{Ti}, \mathrm{V})$, second $(\mathrm{Y}, \mathrm{Zr}, \mathrm{Nb})$, and third transition series (rare earths: $\mathrm{La}, \mathrm{Ce}, \mathrm{Eu}, \mathrm{Tb}, \mathrm{Hf}, \mathrm{Ta}$ ) plus $\mathrm{Th}$ are given in Tables 12 to 16. Because of the similarities of their

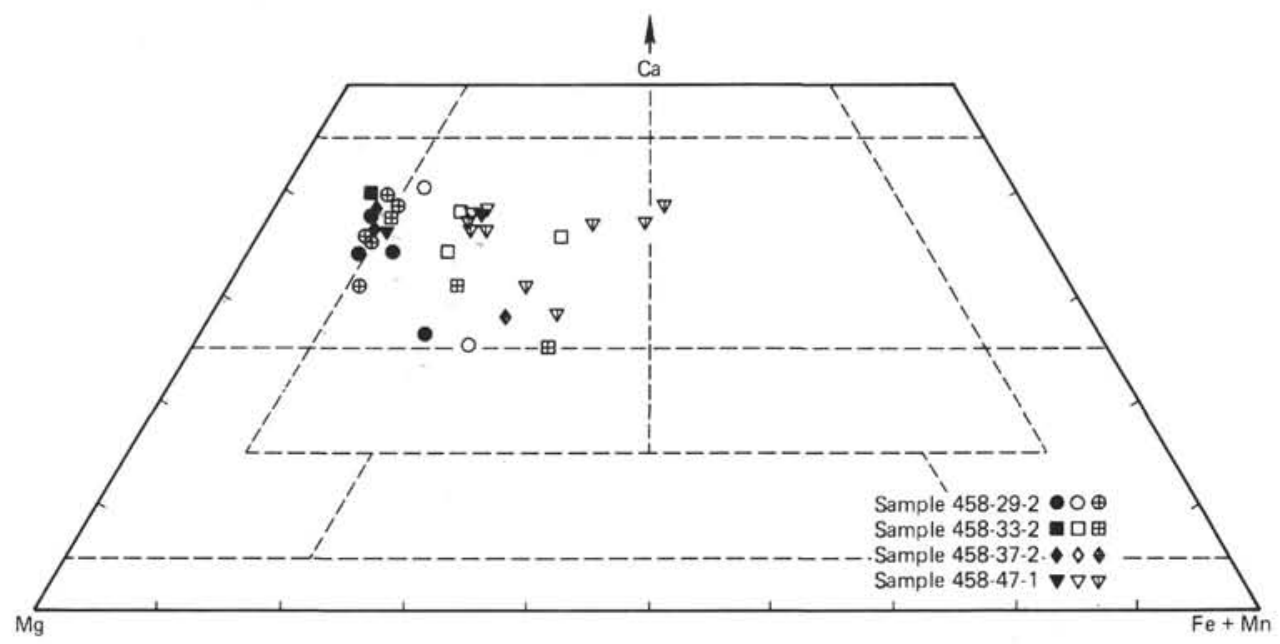

Figure 2. Hole 458: Clinopyroxene composition from lavas. (Black symbols = cores of phenocrysts, open symbols = rims of phenocrysts, symbols with crosses or lines = matrix.) 
chemical and physical properties, the elements of the pairs Y-Tb (group IIIA), Zr-Hf (group IVA), and NbTa (group VA) do not fractionate or fractionate very little with respect to each other during magmatic processes. This has been shown to be the case for oceanic tholeiites (Bougault et al., 1979). We shall first, then, examine the behavior of these three pairs of elements according to the two main groups of samples recovered, respectively, at Sites 454 and 456 (tholeiites) on the one hand and 458 and 459 on the other (basaltic andesites and andesites).

$\mathrm{Y}$ is plotted versus $\mathrm{Tb}$ in Figure 3. As expected, there is a very good correlation between both elements; the data plots near a straight line passing through the origin. The $\mathrm{Y} / \mathrm{Tb}$ ratio observed in abyssal tholeiites (Bougault et al., 1979) is between 40 and 50, close to the chondritic ratio of 46 , taking $2.16 \mathrm{ppm}$ for $\mathrm{Y}$ and 0.047 $\mathrm{ppm}$ for $\mathrm{Tb}$ as average values in chondrites. The ratio defined by the line in Figure 3, about 50, is in the upper range of $\mathrm{Y} / \mathrm{Tb}$ ratios observed for oceanic tholeiites. We note that there is no significant difference between the two groups of samples at Sites 454 and 456 on the one hand and 458 and 459 on the other.

The plot $\mathrm{Hf}-\mathrm{Zr}$ is presented in Figure 4. It is also represented by a straight line passing through the origin; the ratio $\mathrm{Zr} / \mathrm{Hf}$ is 40 ; this ratio, together with the dispersion of points around the line, is also the same as for oceanic tholeiites-the chondrite ratio. Again, there is no significant difference between Holes 454 and 456 and 458 and 459 .

$\mathrm{Nb}$ and $\mathrm{Ta}$ are plotted in Figure 5. The cross represents the reproducibility of measurements, which is not in the confidence range of absolute values. It seems that the $\mathrm{Nb} / \mathrm{Ta}$ ratio presents a slight difference between Holes 454 and 456 and 458 and 459 . Although the average ratio is higher than the ratio observed in oceanic tholeiites (18), the difference is probably not analytically different, given the precision of the measurements. In addition to the reproducibility of measurements themselves, the absolute concentration in $\mathrm{Nb}$ cannot be specified with a precision better than $1 \mathrm{ppm}$. Thus if $\mathrm{Nb}$ concentrations have been overestimated by $1 \mathrm{ppm}$, the corrected $\mathrm{Nb} / \mathrm{Ta}$ ratio would correspond to the ratio already observed in oceanic rocks. This is highly probable, especially if we take into account the results obtained for the two other pairs, $\mathrm{Zr}$-Hf and $\mathrm{Y}-\mathrm{Tb}$, which have ratios identical to oceanic basalts.

In spite of the $\mathrm{Nb} / \mathrm{Ta}$ ratio, which has to be interpreted with analytical precision in mind, we can affirm that the three pairs of elements $\mathrm{Nb}-\mathrm{Ta}, \mathrm{Zr}-\mathrm{Hf}$, and $\mathrm{Y}-\mathrm{Tb}$ present the ratios observed in oceanic rocks and that there are no significant differences between the tholeiites and the basaltic andesites and andesites.

\section{Behavior of Hygromagmaphile Elements: The Use of an Extended Coryell-Masuda Plot}

The adjective "hygromagmaphile" was first introduced by Treuil (1973) to emphasize that the behavior of low partition coefficient elements is not a question only of incompatibility in a crystal structure (the notion of L.I.L. elements) but also of affinity for the liquid. Tak-

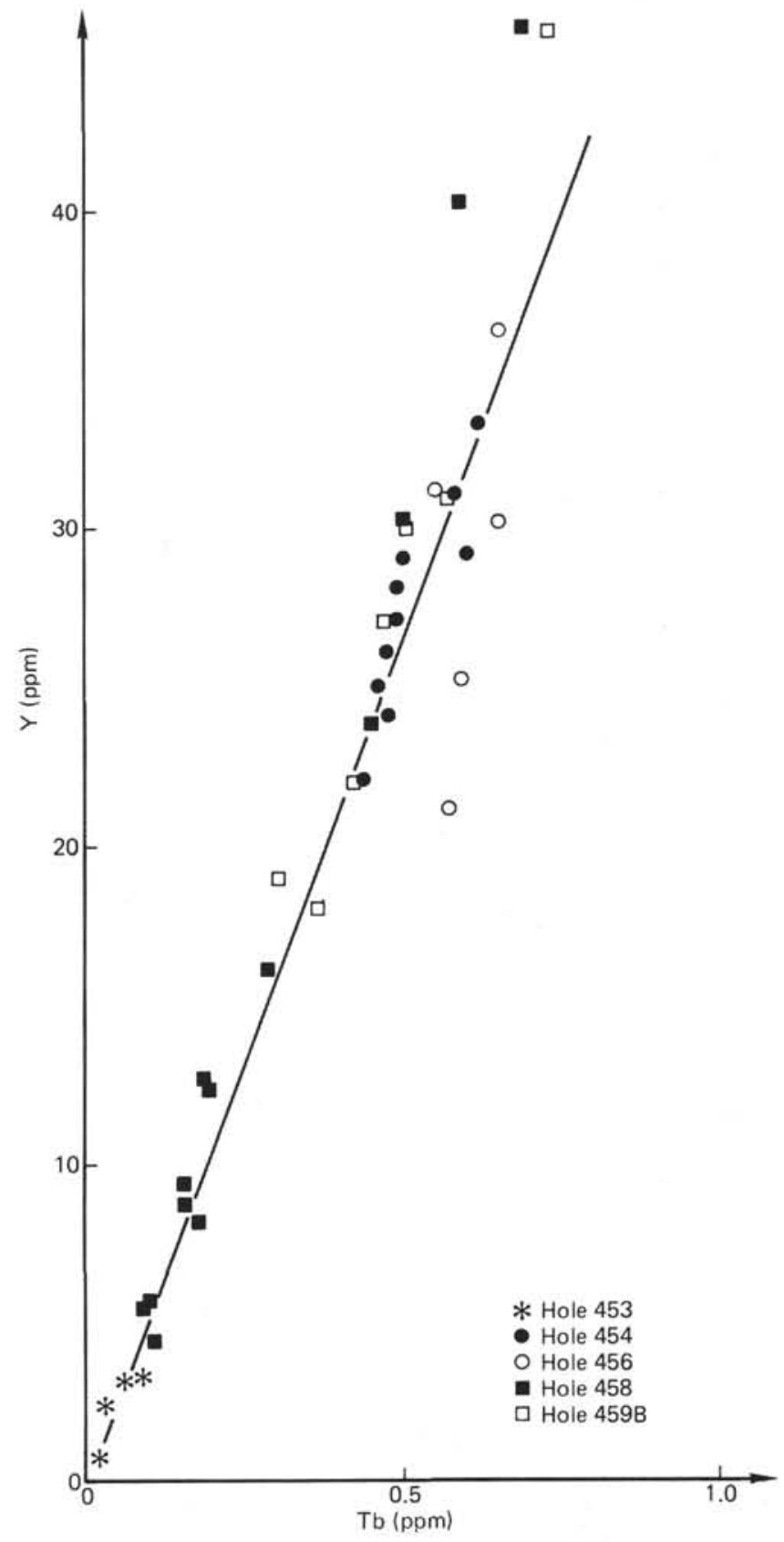

Figure 3. Y versus $\mathrm{Tb}$, all samples.

ing both notions into consideration it has been shown that the low partition coefficient elements can be classified according their "bulk" partition coefficients, at least as far as oceanic tholeiites are concerned (Bougault et al., 1979). Recently, Sun et al. (in press) and Wood et al. (1979) proposed an extension of the plot of Coryell and Masuda (Masuda, 1962; Coryell et al., 1963) including other elements besides rare earths. It can be shown that not all elements can be included in such a plot, but only lithophile and hygromagmaphile elements (Bougault et al, in preparation). The big difficulty in making such an extended Coryell-Masuda plot is the knowledge of chondritic average concentrations for elements such as $\mathrm{Th}, \mathrm{Ta}, \mathrm{Nb}, \mathrm{Zr}$, and $\mathrm{Hf}$. We have deter- 


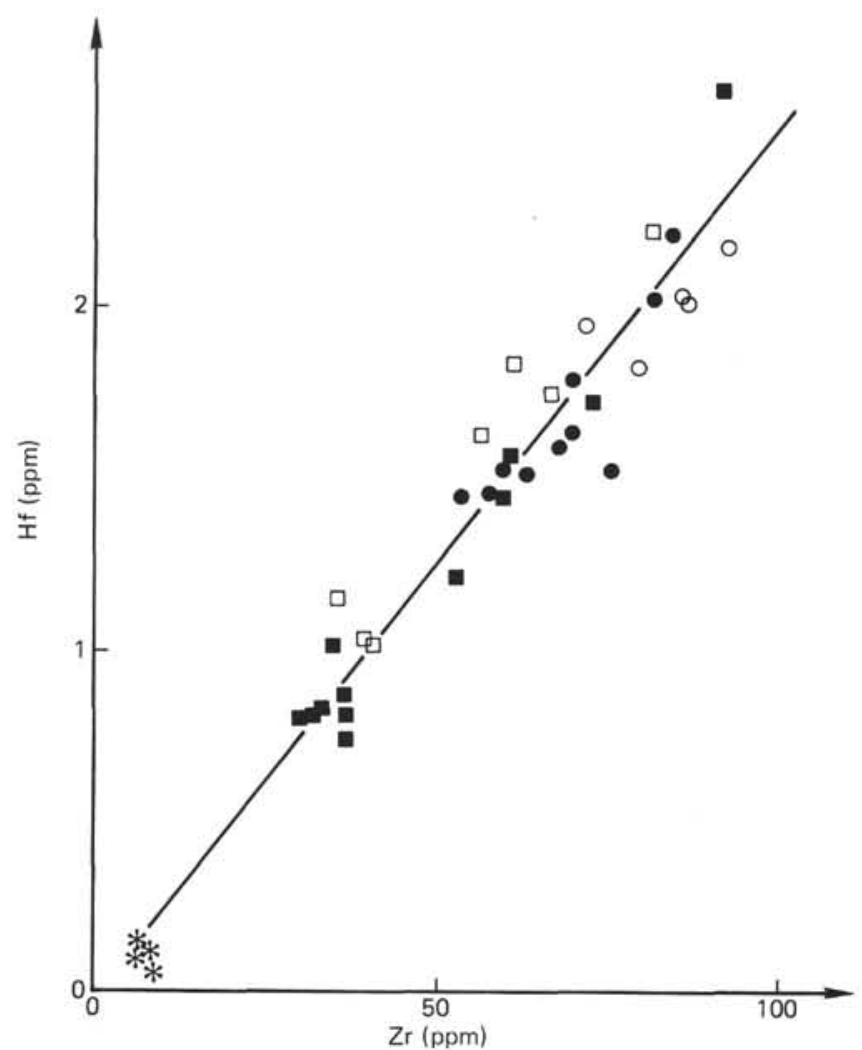

Figure 4. $\mathrm{Zr}$ versus Hf. (Symbols same as in Fig. 3.)

mined theoretical chondritic concentrations through comparative geochemistry of several oceanic basalts (Table 17) and the precise locations where these elements should be plotted with respect to the rare earths. These locations confirm the previous classification of these elements comparative to rare earths (Bougault et al., 1979). From a theoretical point of view we propose the following relationship to account for both the incompatible and hygromagmaphile character of these elements:

$$
\phi=\left(a \Delta R_{i}^{2}+1\right) \frac{n}{R_{i}},
$$

where $R_{i}$ is the ionic radius of the low partition coefficient element, $n$ its charge, and $\Delta R_{i}$ the difference between the ionic radius of the element and the major element for which it substitutes in the crystal structure. The parameter $a$ represents the relative weight of the incompatibility and the hygromagmaphile character. This relationship allows us to place the elements $\mathrm{Th}, \mathrm{Ta}, \mathrm{Nb}$, $\mathrm{Zr}, \mathrm{Hf}, \mathrm{Ti}$, and $\mathrm{Y}$ in exactly the same position as they occupy in the comparative geochemistry (Bougault et al., in preparation). Thus rather than present a CoryellMasuda plot based on atomic numbers (which is somewhat difficult for non-rare-earth elements), the extended Coryell-Masuda plots in the present chapter are based on the parameter $\phi$ plotted against the abscissa. An example is given in Figure 6 for Mid-Atlantic Ridge basalts, $45^{\circ} \mathrm{N}$, FAMOUS area and Leg 37 , and $22^{\circ} \mathrm{N}$ (Leg 45). On this figure can be seen the difference in

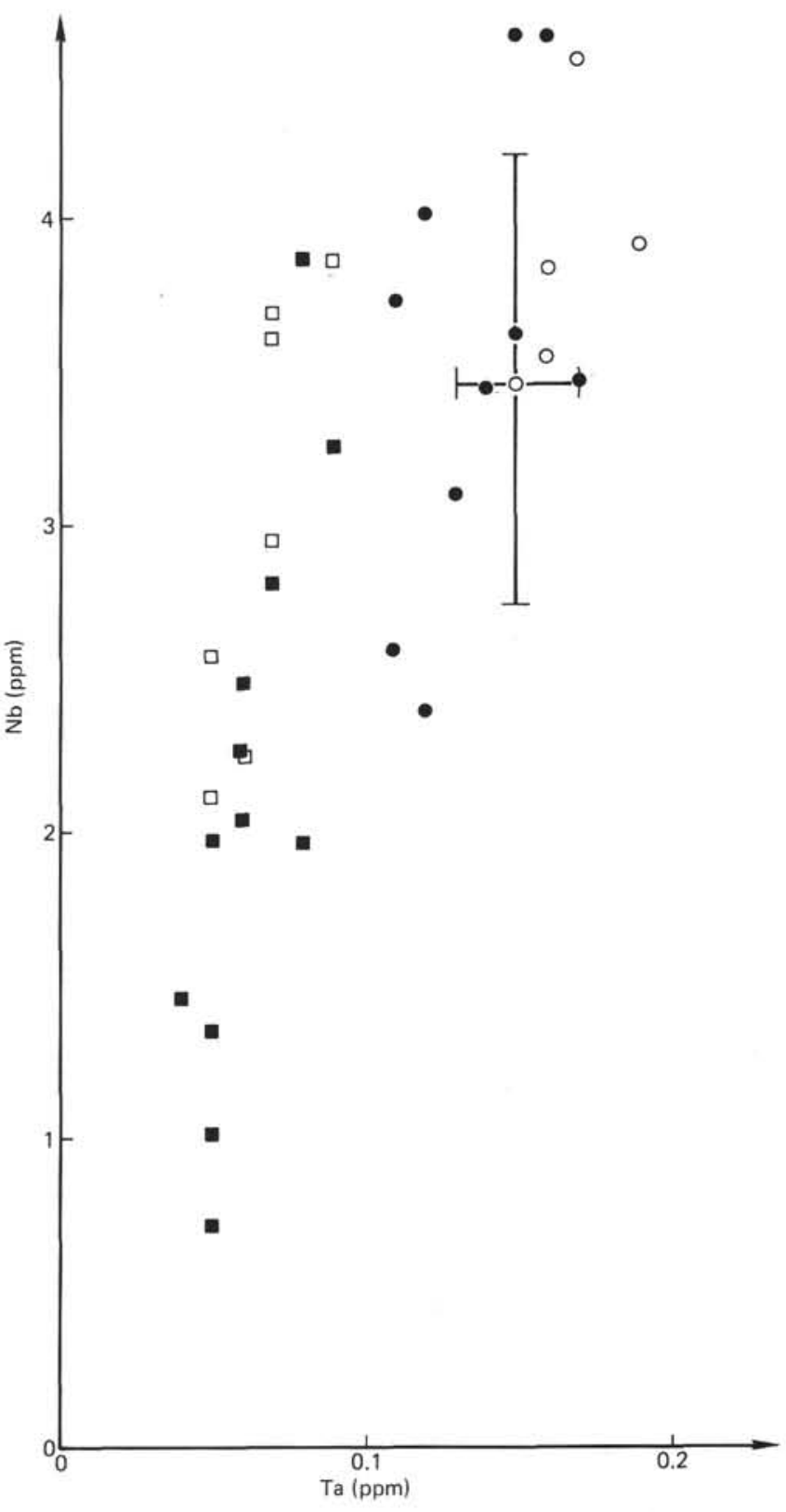

Figure 5. Nb versus Ta. (Symbols same as in Fig. 3.)

$\mathrm{Ta} / \mathrm{La}$ ratio beween the FAMOUS area $\left(37^{\circ} \mathrm{N}\right.$ and $45^{\circ} \mathrm{N}$ on the one hand and $22^{\circ} \mathrm{N}$ on the other, a difference described elsewhere by Bougault et al. (in preparation).

The extended Coryell-Masuda plot for Sites 454 and 456 is presented in Figure 7. These plots are very similar to mid-ocean ridge tholeiites with flat to light rareearth-depleted patterns. They resemble what have been called normal or "depleted" tholeiites, such as $22^{\circ} \mathrm{N}$ samples (Fig. 6). Samples from Sites 454 and 456 show the same " $\mathrm{Ta}, \mathrm{Nb}$ anomaly" ${ }^{5}$ as $22^{\circ} \mathrm{N}$ samples (Fig. 6).

5 "Ta, $\mathrm{Nb}$ anomaly" means that $\mathrm{Ta}$ and $\mathrm{Nb}$ normalized values are different (and lower) than the La normalized values. It has been shown that transitional to alkalic affinity basalts have the same $\mathrm{Ta}, \mathrm{Nb}$, and La normalized values (Fig. 6); this is not the case for $22^{\circ} \mathrm{N}$ samples. The notion of " $\mathrm{Ta}, \mathrm{Nb}$ anomaly" corresponds to the two different $\mathrm{La} / \mathrm{Ta}$ ratios found in the FAMOUS area at $30^{\circ} \mathrm{N}$ and at $22^{\circ} \mathrm{N}$ (Bougault et al., 1978). 


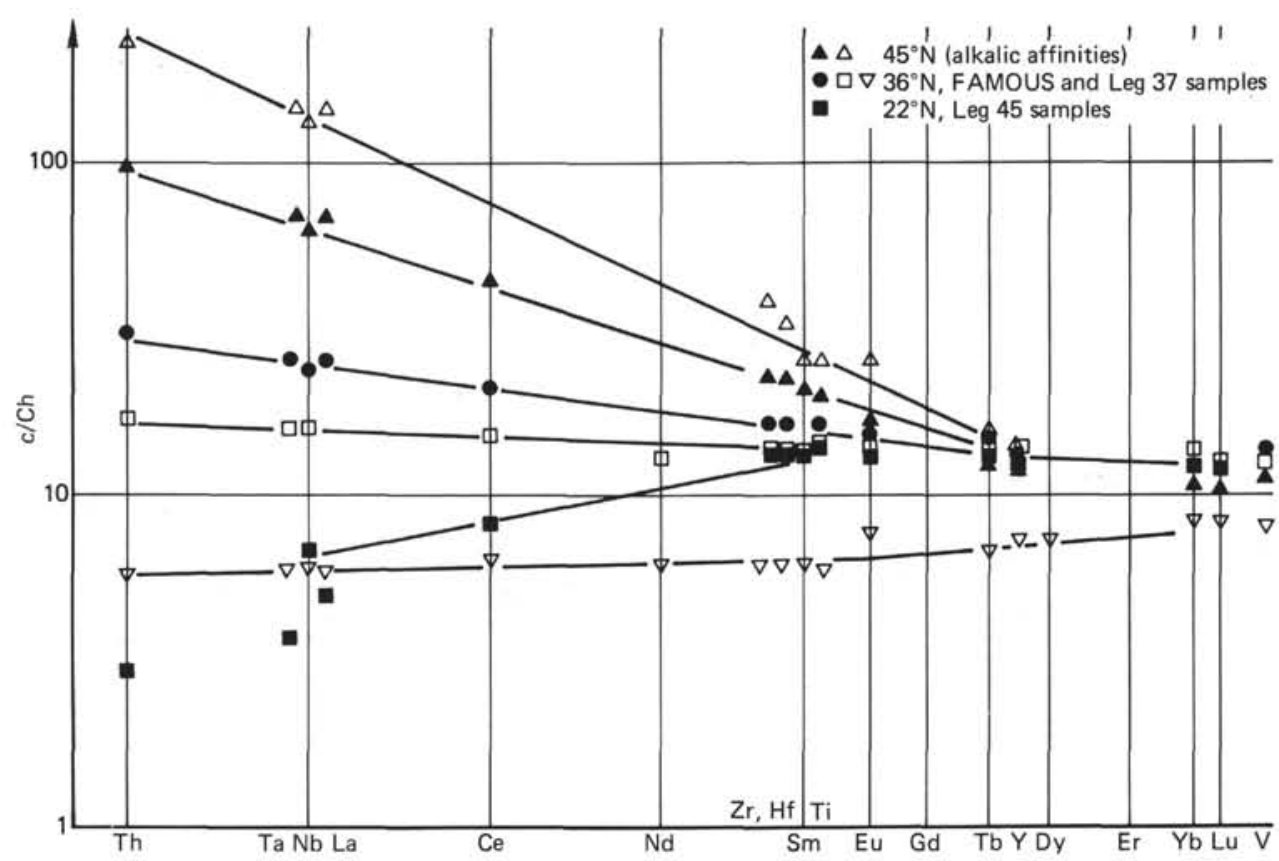

Figure 6. North Atlantic: Examples of normalized chrondrite abundances.
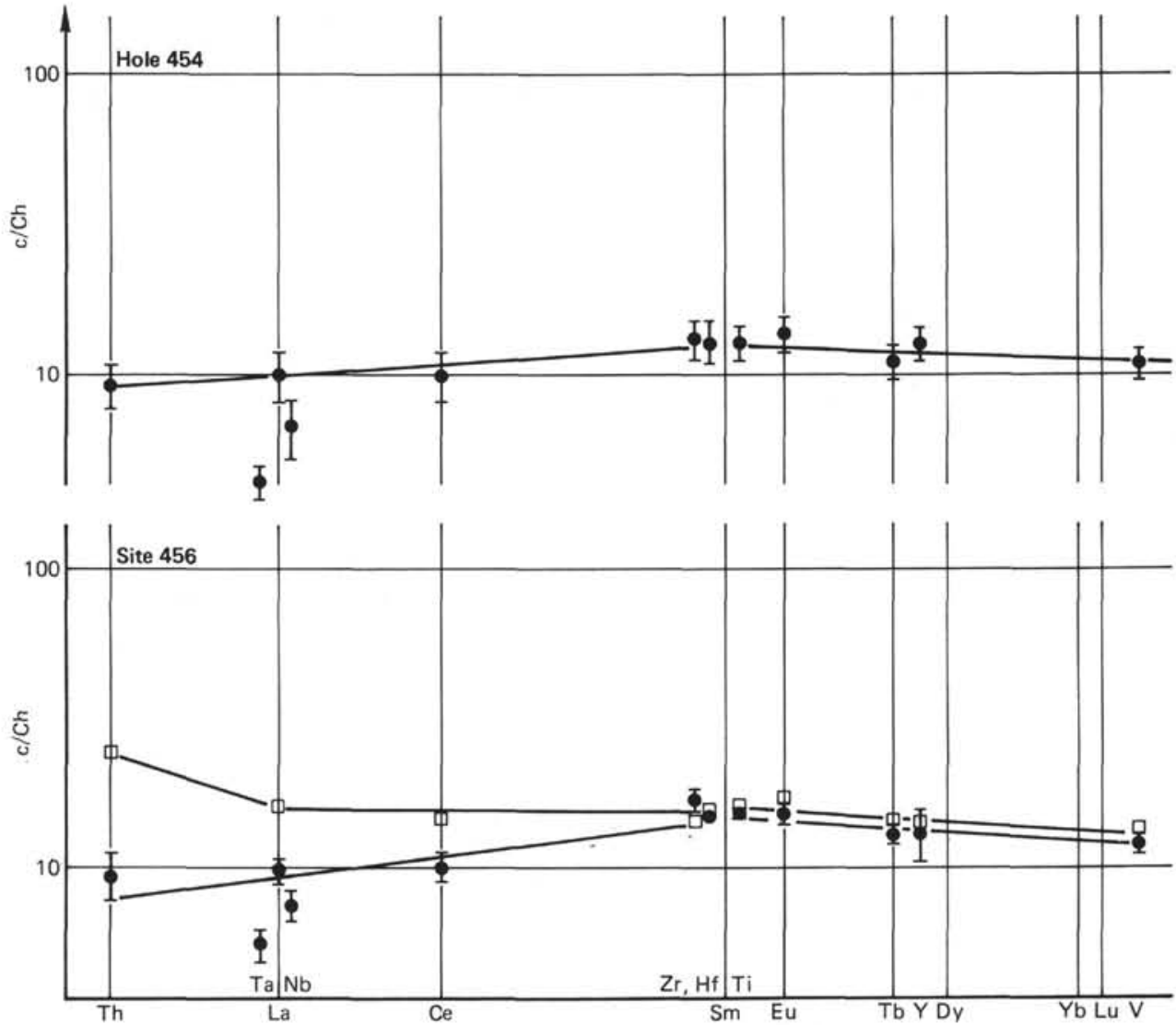

Figure 7. Normalized chondrite abundances for Hole 454 and Site 456 . For Hole 454 and Site 456 the limits corresponding to dots are related to the range of variation in the hole or site. For Hole 456A, Sample 456A-12-1, 62-64 cm (open squares) is outside the limits. 
Figure 8 shows the extended Coryell-Masuda plot for Sites 458 and 459 . On the basis of these patterns, Hole 458 samples can be divided into two groups: (1) samples from Cores 28 to 40 , plus Samples 458-44-1 and 45854-58 (boninite affinity), and (2) others. Group 1 presents two characteristic features: low rare earth content and $\mathrm{Zr}, \mathrm{Hf}$, and $\mathrm{Ti}$ anomalies compared to oceanic tholeiites. These anomalies are characterized by higher chondrite normalized ratios compared to adjacent rare earths $(\mathrm{Eu}, \mathrm{Tb})$; in addition there is fractionation of $\mathrm{Zr}$, and $\mathrm{Hf}$ with respect to Ti. For comparison, the data of Dietrich et al. (1978) from the Marianas region are plotted in Figure 9. The samples of dredges 1398 and 1404 have characteristic patterns of tholeiites. This is obviously not the case for sample of dredge 1402, which has shoshonitic affinities, and probably not the case for basalts of 1402 , which present a fractionation of heavy rare earths. The boninite type rocks of dredge 1403 show similar features with Group 1 in Hole 458: low abundances of rare earths and $\mathrm{Zr}$-Ti fractionation. In addition, in both cases $\mathrm{V}$ does not plot on the rare earth pattern. Whether a similar phenomenon occurs among Leg 60 samples needs to be confirmed by analysis of heavy rare earth elements. In the lower middle part of the diagram, from $\mathrm{Zr}$ to $\mathrm{Y}$, the points are linked by a continuous line to emphasize the atypical behavior of these elements at Sites 458 and 459 samples compared with the typical behavior of tholeiites, which should be represented by the discontinuous line (rare earth curve).

Considering Group 2, those samples of Hole 458 with higher rare earth abundances have less, even negligible, fractionation of $\mathrm{Zr}$ and $\mathrm{Hf}$ with respect to $\mathrm{Ti}$, but the chondrite normalized abundances of these three elements are still higher than those of $\mathrm{Eu}$ and $\mathrm{Tb}$. $\mathrm{Al}$ though to a lesser degree, the same feature is observed among Hole 459B samples. All samples from Sites 458 and 459 show a higher $\mathrm{Y} / \mathrm{Tb}$ ratio than chondrites.

All samples in Group 1 in Hole 458 are glassy or aphyric and may be considered to represent liquid compositions. The difference in the behavior of hygromagmaphile elements between these rocks and the tholeiites at Sites 454 and 456 is probably due to major differences both in the initial solid materials and in the manner of melting.

From the figures presented, it is easy to see that the diagram Zr, Ti, Y proposed by Pearce and Cann (1973) distinguishes no significant differences among oceanic tholeiites. For oceanic tholeiites, $\mathrm{Zr}$ and $\mathrm{Ti}$ do not fractionate with respect to each other (Bougault et al., 1978), and the Pearce-Cann diagram is limited to the fractionation of $\mathrm{Zr}$ and $\mathrm{Ti}$ with respect to $\mathrm{Y}$. From the position of these elements in the extended CoryellMasuda plot it is clear that the fractionation is the same as that of Sm with respect to $\mathrm{Tb}$. We know that such
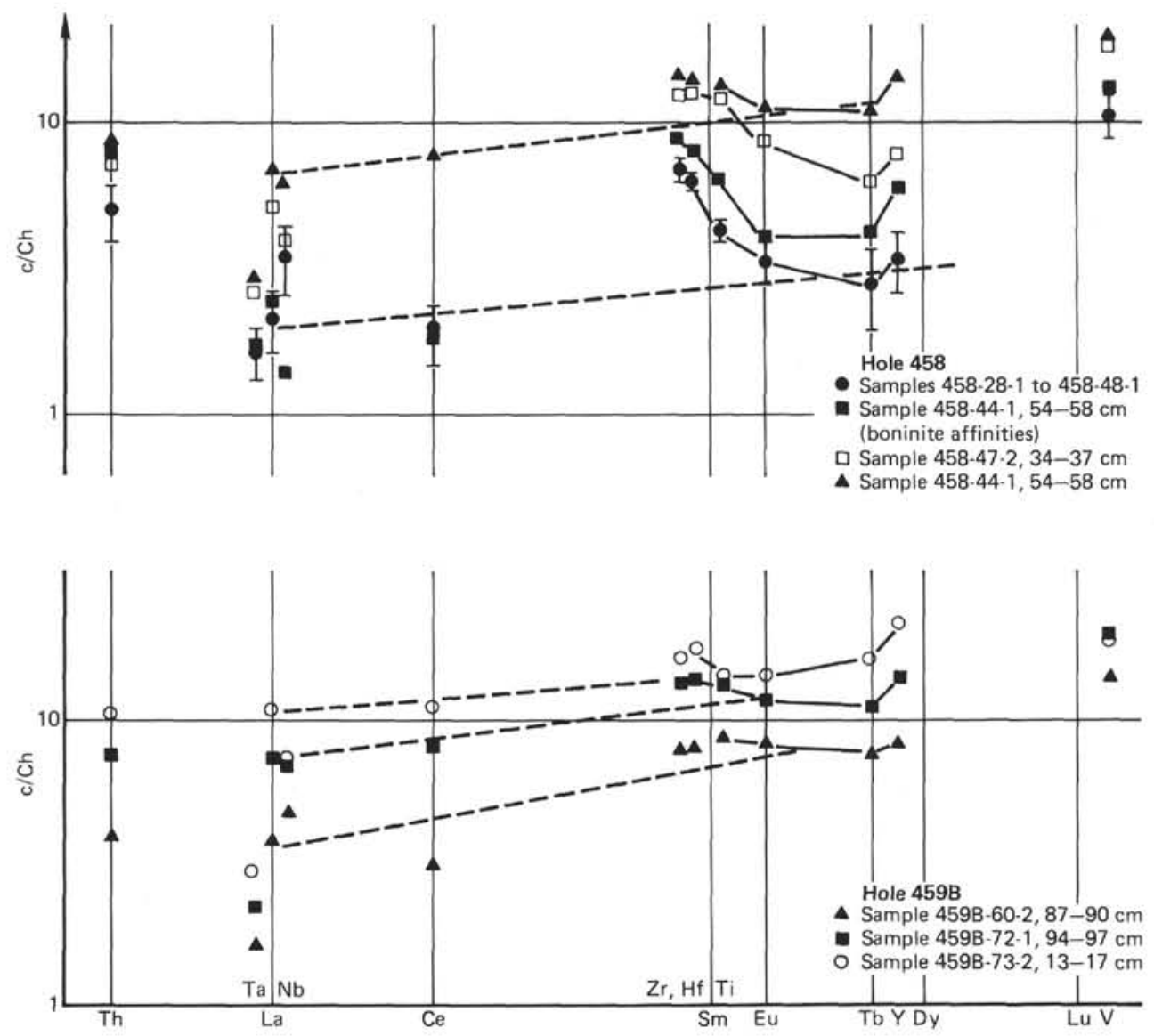

Figure 8. Normalized chondrite abundances for Holes 458 and 459B. 


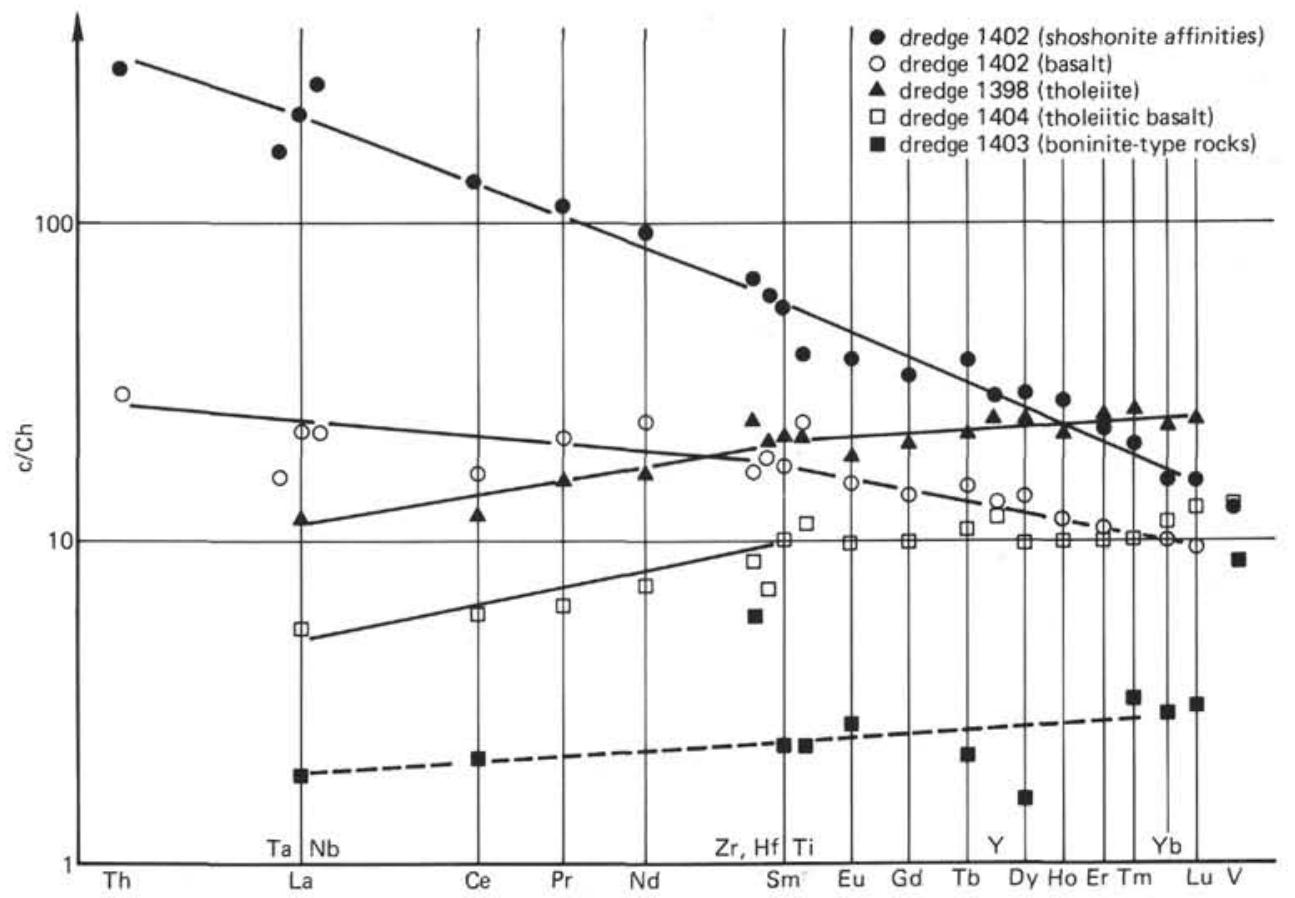

Figure 9. Normalized chondrite abundances from Dietrich et al. (1978).

fractionation is very slight among oceanic tholeiites. By contrast, the Pearce-Cann diagram would show significant differences between Site 458 samples and oceanic tholeiites because of the fractionation of $\mathrm{Zr}, \mathrm{Ti}$, and $\mathrm{Y}$ in these rocks. Nevertheless we prefer to use the proposed extended Coryell-Masuda plot, which emphasizes the same features but at the same time allows a comparison of several hygromagmaphile elements.

\section{CONCLUSIONS}

Major element composition and mineralogy define samples recovered at Sites 454 and 456 as oceanic tholeiites. The extended Coryell-Masuda plots, including within rare earths other low partition coefficient elements, correspond to typical light-rare-earth-depleted tholeiites with a $\mathrm{La} / \mathrm{Ta}$ ratio about 20 (this ratio is about 9 in tholeiites which have flat- or light-rare-earth-enriched patterns).

The samples recovered at Sites 458 and 459 are basaltic andesites or andesites, based on major element compositions and mineralogy. The bronzite andesite Sample 458-44-1 may be considered as a member of the boninite group; it shows a very complex pyroxene mineralogy (bronzite and ferro-augite phenocrysts and wide compositional range in the matrix). The extended Coryell-Masuda plots show three major differences between these rocks and tholeiites: The absolute abundances of rare earths and other low partition coefficient elements are lower than in tholeiites, the $\mathrm{Zr}$-Hf pair does not plot on the line defined by rare earths, and fractionation exists with respect to $\mathrm{Ti}$.

\section{REFERENCES}

Albarede, F., and Bottinga, Y., 1972. Kinetic disequilibrium in trace element partitioning between phenocrysts and host lava. Geochim. Cosmochim. Acta, 36:141-156.
Bougault, H., Joron, J. L., and Treuil, M., 1979. Alteration, fractional crystallization, partial melting, mantle properties from trace elements in basalts recovered in the North Atlantic. Maurice Ewing Series, Vol. 2 (A.G.U.), Deep Drilling Results in the Atlantic ocean; Ocean Crust.

Bougault, H., Treuil, M., and Joron, J. L., 1978. Trace elements in basalts from $23^{\circ} \mathrm{N}$ and $36^{\circ} \mathrm{N}$ in the Atlantic Ocean: fractional crystallization, partial melting, and heterogeneity of the upper mantle. In Melson, W. G., Rabinowitz, P. D., et al., Init. Repts. DSDP, 45: Washington (U.S. Govt. Printing Office), 493-506.

Bougault, H., Treuil, M., and Joron, J. L., in preparation. Comparative geochemistry of transition elements in oceanic basalts.

Coryell, C. D., Chase, J. W., and Winchester, J. W., 1963. A procedure for geochemical interpretation of terrestrial rare earth abundance patterns. J. Geophys. Res., 68:559-566.

Dietrich, V., Eimmerman, R., Oberhansli, R., et al., 1978. Geochemistry of basaltic and Gabbroic rocks from the West Mariana basin and the Mariana trench. Earth Planet. Sci. Lett., 39:127-144.

Ewart, A., 1976. Mineralogy and chemistry of modern orogenic lavassome statistics and implications. Earth Planet. Sci. Lett., 31: 417-432.

Konda, T., 1970. Endiopside in the calcalkaline basalt in the Ryozen area. J. Geol. Soc. Jpn, , 76:7-12. (In Japanese)

Kuroda, N., Shiraki, K., and Urano, H., 1978. Boninite as a possible calc-alkalic primary magma. Proc. Tokyo Conf., pp. 280-281.

Leeman, W. P., and Scheidegger, K. F., 1977. Olivine/liquid distribution coefficients as a test for crystal liquid equilibrium. Earth Planet. Sci. Lett., 35:247-257.

Le Guen de Kerneizon, M., Mascle, A., Maury, R. C., et al., 1979. Les laves de la Désirade (Petites Antilles), témoins d'un magmatisme de marge active; arguments minéralogiques. Bull. Bur. Rech. Geol. Min. 4(3/4):285-292.

Lowder, G. G., 1970. The volcanoes and caldera of Talasea, New Britain: Mineralogy. Contrib. Mineral. Petrol., 26:324-340.

Masuda, A., 1962. Regularities in variation of relative abundances of lanthanide elements and an attempt to analyze separation index patterns of some minerals. J. Earth Sci., Nagoya Univ., 10:173187.

Mevel, C., Ohnenstetter, D., and Ohnenstetter, M., 1979. Mineralogy and petrology of Leg 46 basalts. In Dmitriev, L., Heirtzler, J., et al., Init. Repts. DSDP, 46: Washington (U.S. Govt. Printing Office), 151-164. 
Muir, I. D, and Tilley, C. E., 1964. Basalts from the northern part of the rift zone of the Mid-Atlantic Ridge. J. Petrol., 5:409-434.

Nisbet, E. G., and Pearce, J. A., 1977. Clinopyroxene composition in mafic lavas from different tectonic settings. Contrib. Mineral. Petrol., 63:149-160.

Pearce, J. A., and Cann, J. R., 1973. Tectonic setting of basic volcanic rocks determined using trace element analyses. Earth Planet. Sci. Lett., 19:290-300.

Sun, S. S., Nesbitt, R. W., and Sharaskin, A. Y., in press. Geochemical characteristics of mid-ocean ridge basalts. E.P.S.L.

Treuil, M., 1973. Critères pétrologiques, géochimiques et structuraux de la génèse et de la différenciation des magmas basaltiques; exemple de l'Afar [Thèse de doctorat d'Etat]. Orléans.
Wells, P. R. A., 1977. Pyroxene thermometry in simple and complex systems. Contrib. Mineral. Petrol., 62:129-139.

Wood, A., Tarney, J., Varet, J., et al., 1979b. Geochemistry of basalts drilled in the North Atlantic by IPOD Leg 49: Implications for mantle heterogeneity. Earth Planet. Sci. Lett., 42:77-97.

Wood, B. J., and Banno, S., 1973. Garnet-orthopyroxene and orthopyroxene-clinopyroxene relationships in simple and complex systems. Contrib. Mineral. Petrol., 42:109-124.

Wood, D. A., Varet, J., Bougault, H., et al., 1979a. The petrology, geochemistry and mineralogy of North Atlantic basalts: A discussion based on IPOD Leg 49. In Luyendyk, B. P., Cann, J. R., et al., Init. Repts. DSDP, 49: Washington (U.S. Govt. Printing Office), 597-655. 
Table 1. Hole 454: Major elements and C.I.P.W. norms.

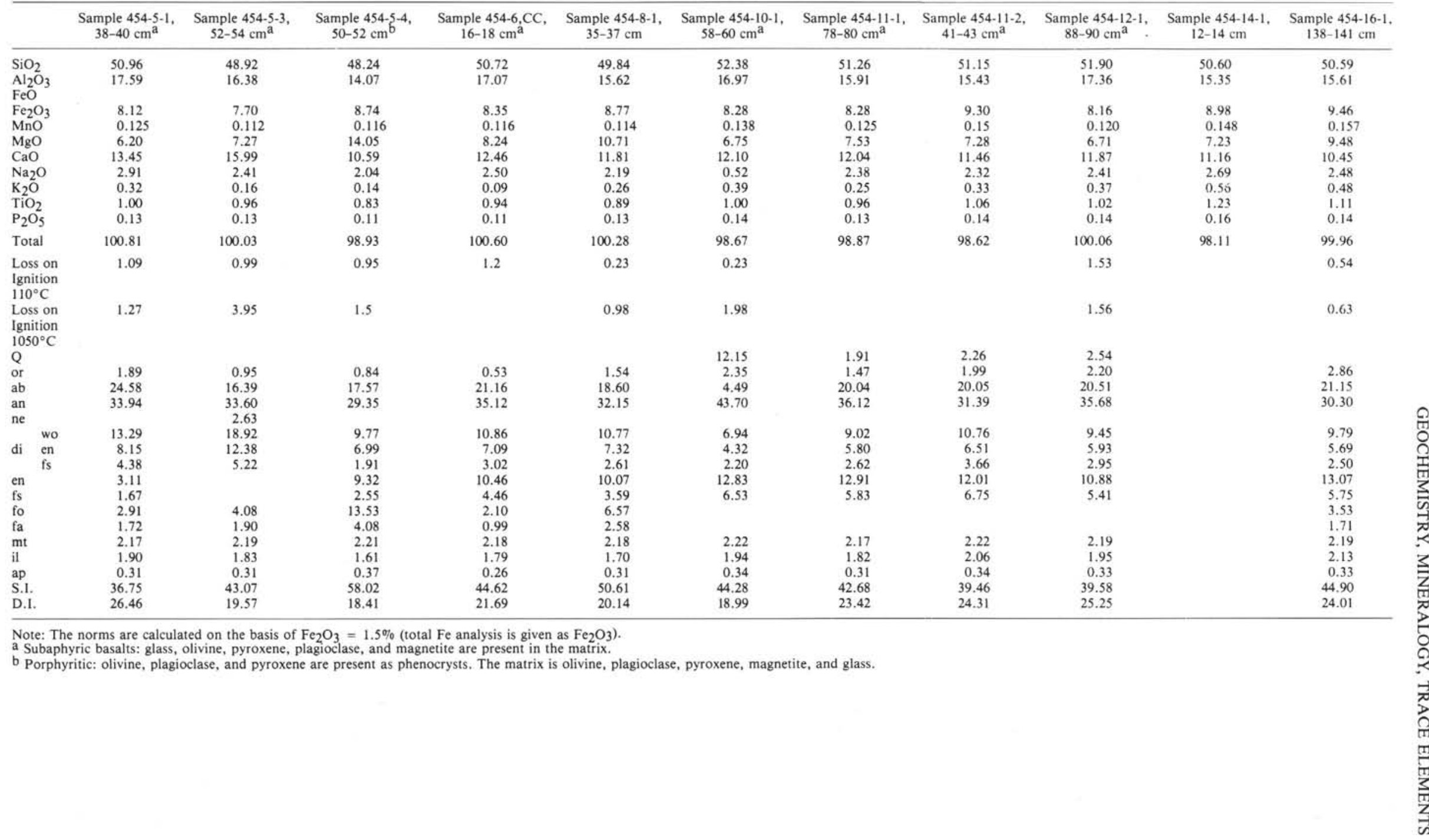


Table 2. Hole 454: Sample 454-8-1, spinel analyses normalized to 32 oxygens.

\begin{tabular}{lrrrrr}
\hline Analysis & \multicolumn{1}{c}{1} & \multicolumn{1}{c}{2} & \multicolumn{1}{c}{3} & \multicolumn{1}{c}{4} & \multicolumn{1}{c}{5} \\
\hline $\mathrm{SiO}_{2}$ & 0.09 & 0.00 & 0.10 & 0.10 & 0.34 \\
$\mathrm{TiO}_{2}$ & 0.48 & 0.42 & 0.40 & 0.41 & 0.46 \\
$\mathrm{Al}_{2} \mathrm{O}_{3}$ & 26.56 & 25.58 & 25.62 & 26.92 & 23.05 \\
$\mathrm{Cr}_{2} \mathrm{O}_{3}$ & 36.76 & 39.29 & 39.77 & 39.25 & 41.47 \\
$\mathrm{Fe}_{2} \mathrm{O}_{3}$ & 7.93 & 6.97 & 5.91 & 5.42 & 6.59 \\
$\mathrm{FeO}$ & 12.27 & 12.71 & 13.06 & 11.91 & 12.58 \\
$\mathrm{MnO}$ & 0.18 & 0.15 & 0.14 & 0.04 & 0.07 \\
$\mathrm{MgO}$ & 15.75 & 15.50 & 15.16 & 16.15 & 15.14 \\
$\mathrm{CaO}$ & 0.00 & 0.14 & 0.01 & 0.00 & 0.08 \\
$\mathrm{Na} 2 \mathrm{O}$ & 0.04 & 0.00 & 0.00 & 0.00 & 0.00 \\
$\mathrm{~K} 2 \mathrm{O}$ & 0.00 & 0.00 & 0.00 & 0.00 & 0.01 \\
$\mathrm{Total}$ & 100.06 & 100.76 & 100.17 & 100.30 & 99.79 \\
$\mathrm{Si}$ & 0.022 & 0.000 & 0.025 & 0.023 & 0.083 \\
$\mathrm{Ti}$ & 0.086 & 0.075 & 0.072 & 0.073 & 0.084 \\
$\mathrm{Al}$ & 7.456 & 7.181 & 7.232 & 7.506 & 6.586 \\
$\mathrm{Cr}$ & 6.923 & 7.401 & 7.531 & 7.361 & 7.949 \\
$\mathrm{Fe}$ & 1.422 & 1.250 & 1.065 & 0.964 & 1.202 \\
$\mathrm{Fe}+$ & 2.445 & 2.532 & 2.617 & 2.356 & 2.551 \\
$\mathrm{Mn}$ & 0.037 & 0.031 & 0.029 & 0.009 & 0.015 \\
$\mathrm{Mg}$ & 5.590 & 5.503 & 5.413 & 5.698 & 5.471 \\
$\mathrm{Ca}$ & 0.000 & 0.036 & 0.003 & 0.000 & 0.021 \\
$\mathrm{Na}$ & 0.020 & 0.000 & 0.000 & 0.000 & 0.000 \\
$\mathrm{~K}$ & 0.000 & 0.000 & 0.000 & 0.000 & 0.002 \\
\hline
\end{tabular}

Note: $\mathrm{Fe}^{2+}$ and $\mathrm{Fe}^{3+}$ estimated from stoichiometry. All microprobe analyses reported in this chapter were performed with a CAMEBAX automatized microprobe (working conditions: $\mathrm{H} 15 \mathrm{kV}, 10-12 \mathrm{nA}$, counting time: $6 \mathrm{~s}$ ).

Table 3. Hole 454: Sample 454-8-1, olivine analyses normalized to 4 oxygens.

\begin{tabular}{lrrrrrrrr}
\hline Analysis & \multicolumn{1}{c}{6} & \multicolumn{1}{c}{7} & \multicolumn{1}{c}{8} & 9 & \multicolumn{1}{c}{10} & 11 & 12 & 13 \\
\hline $\mathrm{SiO}_{2}$ & 40.54 & 41.04 & 40.63 & 41.16 & 40.64 & 41.04 & 40.64 & 40.81 \\
$\mathrm{TiO}_{2}$ & 0.01 & 0.00 & 0.00 & 0.00 & 0.00 & 0.00 & 0.01 & 0.01 \\
$\mathrm{Al}_{2} \mathrm{O}_{3}$ & 0.03 & 0.04 & 0.10 & 0.00 & 0.08 & 0.04 & 0.02 & 0.01 \\
$\mathrm{Cr}_{2} \mathrm{O}_{3}$ & 0.00 & 0.00 & 0.00 & 0.00 & 0.00 & 0.08 & 0.00 & 0.06 \\
$\mathrm{FeO} *$ & 9.73 & 9.70 & 10.20 & 10.19 & 10.48 & 9.70 & 8.95 & 9.29 \\
$\mathrm{MnO}$ & 0.03 & 0.26 & 0.18 & 0.14 & 0.11 & 0.27 & 0.16 & 0.03 \\
$\mathrm{MgO}$ & 48.49 & 48.89 & 48.83 & 48.59 & 49.11 & 49.73 & 49.63 & 48.90 \\
$\mathrm{CaO}$ & 0.19 & 0.32 & 0.30 & 0.27 & 0.26 & 0.25 & 0.27 & 0.35 \\
$\mathrm{Na} 2 \mathrm{O}$ & 0.02 & 0.00 & 0.01 & 0.00 & 0.01 & 0.01 & 0.01 & 0.00 \\
$\mathrm{~K} 2 \mathrm{O}$ & 0.00 & 0.00 & 0.00 & 0.00 & 0.01 & 0.03 & 0.01 & 0.00 \\
$\mathrm{Total}$ & 99.04 & 100.25 & 100.25 & 100.35 & 100.70 & 101.15 & 99.70 & 99.46 \\
$\mathrm{Si}$ & 1.002 & 1.002 & 0.995 & 1.006 & 0.992 & 0.995 & 0.996 & 1.003 \\
$\mathrm{Ti}$ & 0.000 & 0.000 & 0.000 & 0.000 & 0.000 & 0.000 & 0.000 & 0.000 \\
$\mathrm{Al}$ & 0.001 & 0.001 & 0.003 & 0.000 & 0.002 & 0.001 & 0.001 & 0.000 \\
$\mathrm{Cr}$ & 0.000 & 0.000 & 0.000 & 0.000 & 0.000 & 0.002 & 0.000 & 0.001 \\
$\mathrm{Fe}$ & 0.201 & 0.198 & 0.209 & 0.208 & 0.214 & 0.197 & 0.184 & 0.191 \\
$\mathrm{Mn}$ & 0.001 & 0.006 & 0.004 & 0.003 & 0.002 & 0.006 & 0.003 & 0.001 \\
$\mathrm{Mg}$ & 1.786 & 1.780 & 1.783 & 1.770 & 1.788 & 1.797 & 1.812 & 1.791 \\
$\mathrm{Ca}$ & 0.005 & 0.008 & 0.008 & 0.007 & 0.007 & 0.006 & 0.007 & 0.009 \\
$\mathrm{Na}$ & 0.001 & 0.000 & 0.001 & 0.000 & 0.000 & 0.001 & 0.000 & 0.000 \\
$\mathrm{~K}$ & 0.000 & 0.000 & 0.000 & 0.000 & 0.000 & 0.001 & 0.000 & 0.000 \\
$\mathrm{Fo} \%$ & 89.85 & 89.74 & 89.34 & 89.34 & 89.21 & 89.88 & 90.66 & 90.33 \\
\hline
\end{tabular}

Note: 6 : phenocryst $(0=400 \mu \mathrm{m})$ core, $7-10$ : core to rim analyses of a phenocryst about 200 $\mu \mathrm{m}$ large. 11-13: core to rim analyses of a phenceryst about $100 \mu \mathrm{m}$ large. $\mathrm{FeO} *$ : total iron expressed as FeO.
Table 4. Hole 454: Major elements and C.I.P.W. norms of glasses from Sample 454-8-1.

\begin{tabular}{|c|c|c|c|c|c|c|c|}
\hline Analysis & 14 & 15 & 16 & 17 & 18 & 19 & 20 \\
\hline $\mathrm{SiO}_{2}$ & 48.97 & 49.28 & 48.92 & 51.95 & 50.12 & 51.03 & 51.82 \\
\hline $\mathrm{TiO}_{2}$ & 0.85 & 0.97 & 0.90 & 0.88 & 0.98 & 0.96 & 0.99 \\
\hline $\mathrm{Al}_{2} \overline{\mathrm{O}}_{3}$ & 16.41 & 16.52 & 16.47 & 18.25 & 18.23 & 18.55 & 19.77 \\
\hline \multirow{2}{*}{$\begin{array}{l}\mathrm{Cr}_{2} \mathrm{O}_{3} \\
\mathrm{FeO}\end{array}$} & 0.04 & 0.02 & 0.07 & 0.00 & 0.08 & 0.10 & 0.00 \\
\hline & 7.19 & 6.93 & 6.98 & 6.88 & 6.36 & 6.21 & 5.48 \\
\hline $\mathrm{MnO}$ & 0.20 & 0.12 & 0.05 & 0.14 & 0.19 & 0.10 & 0.10 \\
\hline $\mathrm{MgO}$ & 9.35 & 9.26 & 9.3 & 6.81 & 4 & 3. & 2.72 \\
\hline $\mathrm{CaO}$ & 13.50 & 12.99 & 12.96 & 9.87 & 13.35 & 12. & 13.13 \\
\hline $\mathrm{Na}_{2} \mathrm{O}$ & 0.86 & 0.7 & 0.4 & 1.85 & 2.2 & 2.2 & 2.71 \\
\hline $\mathrm{K}_{2} \mathrm{O}$ & 0.19 & 0.13 & 0.17 & 0.24 & 0.1 & 0.23 & 0.30 \\
\hline $\mathrm{P}_{2} \mathrm{O}_{5}$ & 0.32 & 0.3 & 0.32 & 0.15 & 0.29 & 0.26 & 0.42 \\
\hline Total & 97.88 & 97.31 & 96.61 & 97.02 & 96.28 & 96.38 & 97.44 \\
\hline Q & 79 & 5.25 & 6.00 & 7.67 & 4.87 & 6.84 & 6.48 \\
\hline or & 1 & 0.79 & 1.04 & 1.46 & 2 & 11 & 1.82 \\
\hline $\begin{array}{l}a b \\
a n\end{array}$ & 7.42 & 6.08 & 3.59 & 16.10 & 19.75 & 19.56 & 23.48 \\
\hline \multirow[t]{2}{*}{ an } & 41.18 & 42.64 & 44.05 & 41.97 & 40.69 & 41.41 & 41.90 \\
\hline & 10.44 & 8.71 & 8.46 & 3.09 & 10.89 & 9.79 & 9.19 \\
\hline \multirow[t]{2}{*}{ di } & 7.07 & 6.0 & 5.84 & 1.9 & 6.3 & 5.60 & 5.12 \\
\hline & 2.57 & 1.99 & 1.94 & 0.96 & 4.00 & 3.76 & 3.71 \\
\hline en & 16.68 & 17.64 & 18.26 & 15.47 & 4.69 & 4.11 & 1.82 \\
\hline fs & 7 & & 6.05 & 7.04 & 2 & 2.76 & 1.32 \\
\hline $\mathrm{mt}$ & 2.22 & 2 & 2.25 & 2.24 & 2.26 & 2.26 & 2.23 \\
\hline & 1.65 & 1.8 & 1.77 & 1.72 & 1.9 & 1.89 & 1.93 \\
\hline ap & 0.77 & 0.95 & 0.78 & 0.37 & 0.71 & 0.64 & 1.02 \\
\hline S.I & 52.53 & 54.03 & 55.13 & 42.78 & 32.35 & 30.01 & 24.03 \\
\hline D.I. & 11.36 & 12.11 & 10.62 & 25.23 & 25.54 & 27.81 & 31.78 \\
\hline
\end{tabular}

Note: 14-17: glassy matrix, 18-20: glassy inclusions in olivine (18: core; 20: rim),

Table 5. Hole 454: Sample 454-11-2, pyroxene analyses normalized to 8 oxygens.

\begin{tabular}{lrrrrr}
\hline Analysis & \multicolumn{1}{c}{21} & 22 & 23 & 24 & 25 \\
\hline $\mathrm{SiO}_{2}$ & 49.47 & 49.22 & 49.46 & 48.43 & 50.49 \\
$\mathrm{TiO}_{2}$ & 1.30 & 1.60 & 1.20 & 1.73 & 1.31 \\
$\mathrm{Al}_{2} \mathrm{O}_{3}$ & 6.44 & 7.26 & 6.25 & 6.12 & 4.03 \\
$\mathrm{Cr}_{2} \mathrm{O}_{3}$ & 0.00 & 0.00 & 0.04 & 0.16 & 0.01 \\
$\mathrm{FeO}^{*}$ & 6.21 & 6.49 & 6.54 & 8.52 & 12.97 \\
$\mathrm{MnO}$ & 0.00 & 0.14 & 0.13 & 0.11 & 0.14 \\
$\mathrm{MgO}$ & 14.65 & 13.87 & 14.24 & 13.27 & 15.19 \\
$\mathrm{CaO}$ & 20.94 & 20.66 & 20.37 & 20.66 & 14.37 \\
$\mathrm{Na} 2 \mathrm{O}$ & 0.27 & 0.26 & 0.30 & 0.31 & 0.21 \\
$\mathrm{~K} 2 \mathrm{O}$ & 0.00 & 0.00 & 0.00 & 0.00 & 0.00 \\
$\mathrm{Total}$ & 99.28 & 99.50 & 98.53 & 99.31 & 98.72 \\
$\mathrm{Si}$ & 1.823 & 1.813 & 1.839 & 1.805 & 1.893 \\
$\mathrm{Ti}$ & 0.036 & 0.044 & 0.034 & 0.049 & 0.037 \\
$\mathrm{Al}$ & 0.280 & 0.315 & 0.274 & 0.270 & 0.178 \\
$\mathrm{Cr}$ & 0.000 & 0.000 & 0.001 & 0.005 & 0.000 \\
$\mathrm{Fe}$ & 0.191 & 0.200 & 0.203 & 0.267 & 0.407 \\
$\mathrm{Mn}$ & 0.000 & 0.004 & 0.004 & 0.004 & 0.005 \\
$\mathrm{Mg}$ & 0.805 & 0.762 & 0.789 & 0.741 & 0.849 \\
$\mathrm{Ca}$ & 0.827 & 0.815 & 0.811 & 0.829 & 0.577 \\
$\mathrm{Na}$ & 0.019 & 0.019 & 0.021 & 0.022 & 0.015 \\
$\mathrm{~K}$ & 0.000 & 0.000 & 0.000 & 0.000 & 0.000 \\
$\mathrm{Ca}$ & 45.4 & 45.8 & 44.9 & 45.1 & 31.4 \\
$\mathrm{Mg}$ & 44.1 & 42.7 & 43.6 & 40.2 & 46.2 \\
$\mathrm{Fe}+\mathrm{Mn}$ & 10.5 & 11.5 & 11.5 & 14.7 & 22.4 \\
\hline
\end{tabular}

Note: 21 and 22: cores. 23: rim of a phenocryst. 24 and 25: matrix. 
Table 6. Hole 458: Major elements and C.I.P.W. norms.

\begin{tabular}{|c|c|c|c|c|c|c|c|c|c|c|c|c|c|c|c|}
\hline $\begin{array}{l}\text { Sample } \\
\text { (interval in } \mathrm{cm} \text { ) }\end{array}$ & $\begin{array}{l}458-28-1 \\
102-104\end{array}$ & $\begin{array}{c}458-29-2 \\
51-54\end{array}$ & $\begin{array}{c}458-30-2 \\
32-35\end{array}$ & $\begin{array}{l}458-32-3 \\
110-112\end{array}$ & $\begin{array}{l}458-33-2 \\
115-117\end{array}$ & $\begin{array}{c}458-35-2 \\
95-98\end{array}$ & $\begin{array}{c}458-37-2 \\
31-35\end{array}$ & $\begin{array}{c}458-39-3 \\
24-27\end{array}$ & $\begin{array}{l}458-40-1 \\
116-118\end{array}$ & $\begin{array}{c}458-41-1 \\
60-63\end{array}$ & $\begin{array}{c}458-43-1 \\
88-92\end{array}$ & $\begin{array}{c}458-44-1 \\
54-58\end{array}$ & $\begin{array}{c}458-47-1 \\
56-69\end{array}$ & $\begin{array}{c}458-47-2 \\
34-47\end{array}$ & $\begin{array}{c}458-48-1 \\
41-43\end{array}$ \\
\hline $\mathrm{SiO}_{2}$ & 52.97 & 52.55 & 53.32 & 55.77 & 55.50 & 53.39 & 53.12 & 53.58 & 53.60 & 55.03 & 52.62 & 55.78 & 51.99 & 53.86 & 51.98 \\
\hline $\begin{array}{l}\mathrm{Al}_{2} \mathrm{O}_{3} \\
\mathrm{FeO}\end{array}$ & 16.70 & 16.06 & 16.30 & 15.17 & 14.95 & 17.66 & 16.04 & 17.17 & 15.77 & 18.80 & 16.81 & 14.89 & 16.74 & 15.11 & 16.56 \\
\hline $\mathrm{Fe}_{2} \mathrm{O}_{3}$ & 8.89 & 9.26 & 9.11 & 8.44 & 8.28 & 8.90 & 8.78 & 9.76 & 10.16 & 9.98 & 10.20 & 10.34 & 13.47 & 13.12 & 13.54 \\
\hline $\mathrm{MnO}$ & 0.138 & 0.118 & 0.117 & 0.112 & 0.12 & 0.105 & 0.110 & 0.093 & 0.108 & 0.087 & 0.084 & 0.156 & 0.113 & 0.090 & 0.093 \\
\hline $\mathrm{MgO}$ & 6.91 & 8.62 & 8.11 & 5.59 & 6.65 & 5.06 & 6.86 & 6.23 & 8.16 & 1.93 & 5.14 & 7.45 & 5.16 & 4.78 & 5.37 \\
\hline $\mathrm{CaO}$ & 11.73 & 9.58 & 9.20 & 10.81 & 10.88 & 9.81 & 11.28 & 8.79 & 7.44 & 6.34 & 9.83 & 8.35 & 7.35 & 6.18 & 6.72 \\
\hline $\mathrm{Na}_{2} \mathrm{O}$ & 1.93 & 2.23 & 2.26 & 1.94 & 1.98 & 2.31 & 1.98 & 2.34 & 2.10 & 4.34 & 2.65 & 2.07 & 3.00 & 2.89 & 3.02 \\
\hline $\mathrm{K}_{2} \mathrm{O}$ & 0.72 & 0.98 & 1.21 & 0.84 & 0.73 & 1.41 & 1.04 & 1.30 & 1.14 & 1.78 & 2.46 & 0.57 & 0.42 & 0.76 & 0.56 \\
\hline $\mathrm{TiO}_{2}$ & 0.32 & 0.32 & 0.32 & 0.27 & 0.29 & 0.34 & 0.30 & 0.35 & 0.34 & 1.05 & 0.55 & 0.50 & 1.01 & 0.92 & 0.98 \\
\hline $\mathrm{P}_{2} \mathrm{O}_{5}$ & 0.04 & 0.04 & 0.04 & 0.07 & 0.06 & 0.07 & 0.07 & 0.04 & 0.04 & 0.26 & 0.09 & 0.06 & 0.14 & 0.07 & 0.12 \\
\hline Total & 100.35 & 99.76 & 99.99 & 99.01 & 99.44 & 99.06 & 99.58 & 99.75 & 98.86 & 99.60 & 100.43 & 100.17 & 99.36 & 97.78 & 98.94 \\
\hline $\begin{array}{l}\text { Loss on } \\
\text { Ignition } \\
110^{\circ} \mathrm{C}\end{array}$ & 1.82 & 2.81 & 2.91 & 0.81 & 0.83 & 2.29 & 1.12 & 3.71 & 4.09 & 1.52 & 2.95 & 3.01 & 2.96 & 4.36 & 3.18 \\
\hline $\begin{array}{l}\text { Loss on } \\
\text { Ignition } \\
1050^{\circ} \mathrm{C}\end{array}$ & 1.30 & 2.33 & 2.58 & 0.77 & 0.74 & 1.98 & 1.34 & 3.26 & 3.52 & 1.81 & 2.76 & 3.59 & 2.37 & 15.33 & 2.84 \\
\hline Q & 3.83 & 0.99 & 2.03 & 10.58 & 8.99 & 4.59 & 3.82 & 3.93 & 4.74 & 2.89 & & 9.43 & 3.22 & & 3.01 \\
\hline or & 4.27 & 5.85 & 7.20 & 5.05 & 4.37 & 8.47 & 6.22 & 7.77 & 6.87 & 10.65 & 14.60 & 3.39 & 2.53 & & 3.39 \\
\hline$a b$ & 16.39 & 19.05 & 19.26 & 16.69 & 16.96 & 19.87 & 16.94 & 20.03 & 18.12 & 37.17 & 22.51 & 17.63 & 25.85 & & 26.13 \\
\hline $\begin{array}{l}\text { an } \\
\text { ne }\end{array}$ & 34.92 & 31.24 & 31.00 & 30.72 & 30.12 & 34.23 & 32.18 & 32.90 & 30.86 & 26.90 & 26.83 & 29.87 & 31.55 & & 30.67 \\
\hline wo & 9.70 & 6.89 & 6.15 & 9.75 & 10.07 & 6.18 & 10.00 & 4.57 & 2.73 & 1.35 & 9.00 & 4.78 & 1.94 & & 1.10 \\
\hline di en & 5.69 & 4.25 & 3.75 & 5.45 & 6.02 & 3.25 & 5.89 & 2.49 & 1.60 & 0.42 & 4.48 & 2.71 & 0.83 & & 0.48 \\
\hline fs & 3.54 & 2.24 & 2.05 & 3.91 & 3.53 & 2.74 & 3.62 & 1.93 & 1.00 & 0.98 & 4.33 & 1.87 & 1.11 & & 0.62 \\
\hline en & 11.58 & 17.43 & 16.59 & 8.71 & 10.75 & 9.56 & 11.39 & 13.21 & 19.13 & 4.45 & 5.17 & 15.97 & 12.18 & & 13.20 \\
\hline $\begin{array}{l}\text { fs } \\
\text { fo }\end{array}$ & 7.21 & 9.16 & 9.07 & 6.25 & 6.30 & 8.07 & 7.00 & 10.22 & 11.98 & 10.37 & $\begin{array}{l}5.00 \\
2.25\end{array}$ & 11.06 & 16.29 & & 16.99 \\
\hline fa & & & & & & & & & & & 2.40 & & & & \\
\hline $\mathrm{mt}$ & 2.18 & 2.20 & 2.19 & 2.21 & 2.20 & 2.21 & 2.20 & 2.20 & 2.22 & 2.20 & 2.18 & 2.19 & 2.22 & & 2.23 \\
\hline il & 0.61 & 0.61 & 0.61 & 0.52 & 0.56 & 0.66 & 0.58 & 0.67 & 0.66 & 2.02 & 1.05 & 0.96 & 1.95 & & 1.90 \\
\hline ap & 0.10 & 0.10 & 0.10 & 0.17 & 0.14 & 0.17 & 0.17 & 0.10 & 0.62 & 0.21 & 0.21 & 0.14 & 0.34 & & 0.29 \\
\hline S.1. & 39.04 & 42.50 & 40.75 & 34.77 & 39.27 & 29.94 & 28.34 & 33.24 & 39.51 & 11.27 & 26.34 & 38.09 & 24.68 & & 25.30 \\
\hline D.I. & 24.48 & 25.89 & 28.49 & 32.32 & 30.31 & 32.93 & 26.98 & 31.73 & 29.74 & 50.71 & 37.11 & 30.45 & 31.60 & & 32.53 \\
\hline
\end{tabular}

Note: $\mathrm{Fe}_{2} \mathrm{O}_{3}$ : total iron expressed as $\mathrm{Fe}_{2} \mathrm{O}_{3}$. 
Table 7. Hole 458: Sample 458-44-1, pyroxene analyses of bronzite andesite normalized to 6 oxygens.

\begin{tabular}{|c|c|c|c|c|c|c|c|c|c|c|c|c|}
\hline \multirow[b]{2}{*}{ Analysis } & \multicolumn{11}{|c|}{ Phenocrysts } & \multirow[b]{2}{*}{37} \\
\hline & 26 & 27 & 28 & 29 & 30 & 31 & 32 & 33 & 34 & 35 & 36 & \\
\hline $\mathrm{SiO}_{2}$ & 56.37 & 56.88 & 56.22 & 56.70 & 56.26 & 56.38 & 49.63 & 49.27 & 49.68 & 49.20 & 48.65 & 46.03 \\
\hline $\mathrm{TiO}_{2}$ & 0.08 & 0.01 & 0.02 & 0.05 & 0.00 & 0.01 & 0.35 & 0.32 & 0.42 & 0.29 & 0.27 & 0.67 \\
\hline $\mathrm{Al}_{2} \mathrm{O}_{3}$ & 0.64 & 0.63 & 1.01 & 1.59 & 1.92 & 1.35 & 1.22 & 1.32 & 1.25 & 1.20 & 1.29 & 12.04 \\
\hline $\mathrm{Cr}_{2} \mathrm{O}_{3}$ & 0.28 & 0.52 & 0.69 & 0.59 & 0.54 & 0.47 & 0.00 & 0.00 & 0.08 & 0.02 & 0.00 & 0.00 \\
\hline $\mathrm{FeO}^{*}$ & 10.19 & 8.31 & 8.40 & 8.14 & 8.74 & 9.19 & 23.79 & 23.99 & 24.24 & 24.47 & 26.49 & 21.26 \\
\hline $\mathrm{MnO}$ & 0.09 & 0.13 & 0.25 & 0.24 & 0.25 & 0.31 & 0.77 & 1.02 & 0.85 & 0.87 & 1.04 & 0.23 \\
\hline $\mathrm{MgO}$ & 31.76 & 32.12 & 31.48 & 32.49 & 31.73 & 31.34 & 3.94 & 3.56 & 33.94 & 3.39 & 1.70 & 11.66 \\
\hline $\mathrm{CaO}$ & 1.40 & 1.84 & 1.84 & 1.58 & 1.78 & 1.99 & 19.66 & 19.49 & 19.24 & 19.34 & 19.14 & 7.46 \\
\hline $\mathrm{Na}_{2} \mathrm{O}$ & 0.02 & 0.01 & 0.04 & 0.00 & 0.00 & 0.01 & 0.85 & 0.95 & 0.81 & 0.77 & 1.15 & 0.78 \\
\hline $\mathrm{K}_{2} \mathrm{O}$ & 0.00 & 0.00 & 0.00 & 0.00 & 0.01 & 0.00 & 0.02 & 0.00 & 0.00 & 0.00 & 0.00 & 0.02 \\
\hline Total & 100.83 & 100.45 & 99.95 & 101.38 & 101.23 & 101.05 & 100.23 & 99.92 & 99.96 & 99.55 & 99.73 & 100.15 \\
\hline $\mathrm{Si}$ & 1.969 & 1.979 & 1.965 & 1.953 & 1.948 & 1.960 & 1.973 & 1.979 & 1.980 & 1.972 & 1.973 & 1.741 \\
\hline $\mathrm{Ti}$ & 0.002 & 0.000 & 0.001 & 0.001 & 0.000 & 0.000 & 0.011 & 0.010 & 0.012 & 0.009 & 0.008 & 0.019 \\
\hline $\mathrm{Al}$ & 0.027 & 0.026 & 0.042 & 0.065 & 0.078 & 0.055 & 0.057 & 0.063 & 0.059 & 0.057 & 0.062 & 0.537 \\
\hline $\mathrm{Cr}$ & 0.008 & 0.014 & 0.019 & 0.016 & 0.015 & 0.013 & 0.000 & 0.000 & 0.002 & 0.001 & 0.000 & 0.000 \\
\hline $\mathrm{Fe}$ & 0.298 & 0.242 & 0.246 & 0.235 & 0.253 & 0.267 & 0.791 & 0.806 & 0.808 & 0.820 & 0.899 & 0.673 \\
\hline $\mathrm{Mn}$ & 0.003 & 0.004 & 0.007 & 0.007 & 0.007 & 0.006 & 0.026 & 0.035 & 0.029 & 0.030 & 0.036 & 0.007 \\
\hline $\mathrm{Mg}$ & 1.653 & 1.666 & 1.643 & 1.668 & 1.637 & 1.624 & 0.234 & 0.213 & 0.201 & 0.203 & 0.103 & 0.657 \\
\hline $\mathrm{Ca}$ & 0.052 & 0.069 & 0.069 & 0.058 & 0.066 & 0.074 & 0.837 & 0.839 & 0.822 & 0.830 & 0.832 & 0.302 \\
\hline $\mathrm{Na}$ & 0.001 & 0.001 & 0.002 & 0.000 & 0.000 & 0.001 & 0.066 & 0.074 & 0.062 & 0.060 & 0.091 & 0.057 \\
\hline K & 0.000 & 0.000 & 0.000 & 0.000 & 0.001 & 0.000 & 0.001 & 0.000 & 0.000 & 0.000 & 0.000 & 0.001 \\
\hline $\mathrm{Ca}$ & 2.600 & 3.500 & 3.500 & 3.000 & 3.400 & 3.800 & 44.300 & 44.300 & 44.200 & 44.100 & 44.50 & 18.500 \\
\hline $\mathrm{Mg}$ & 82.400 & 84.100 & 83.600 & 84.800 & 83.400 & 82.300 & 12.400 & 11.300 & 10.800 & 10.800 & 5.50 & 40.000 \\
\hline $\mathrm{Fe}+\mathrm{Mn}$ & 15.000 & 12.400 & 12.900 & 12.200 & 13.200 & 13.900 & 43.300 & 44.400 & 45.000 & 45.00 & 50.00 & 41.500 \\
\hline
\end{tabular}

Note: 26 to 36: phenocrysts ( $>100 \mu \mathrm{m}$ ) of bronzite ( 26 to 31 ) and ferroaugite (32-36). 26 and 27: core; 28-31, core to rim analyses of a $200 \mu \mathrm{m}$ in diameter crystal; 32-34: cores; 35 and 36: rims. $37-42: 20-50 \mu \mathrm{m}$ microphenocrysts; 37,39 and $41:$ cores; 38,40 , and 42 : rims; 43-50: microlites $(<20 \mu \mathrm{m})$. 
Table 7. (Continued).

\begin{tabular}{|c|c|c|c|c|c|c|c|c|c|c|c|c|}
\hline \multicolumn{5}{|c|}{ Microphenocrysts } & \multicolumn{8}{|c|}{ Microlites } \\
\hline 38 & 39 & 40 & 41 & 42 & 43 & 44 & 45 & 46 & 47 & 48 & 49 & 50 \\
\hline 55.49 & 55.66 & 45.05 & 50.55 & 53.96 & 50.10 & 47.17 & 46.01 & 44.15 & 55.24 & 55.08 & 50.44 & 54.21 \\
\hline 0.05 & 0.09 & 0.97 & 0.58 & 0.16 & 0.56 & 0.83 & 0.78 & 1.19 & 0.03 & 0.07 & 0.01 & 0.08 \\
\hline 1.13 & 1.15 & 10.55 & 14.55 & 2.83 & 5.63 & 7.90 & 8.53 & 10.34 & 1.14 & 1.18 & 1.11 & 2.58 \\
\hline 0.00 & 0.24 & 0.00 & 0.01 & 0.06 & 0.07 & 0.00 & 0.00 & 0.00 & 0.25 & 0.31 & 0.09 & 0.09 \\
\hline 10.85 & 11.57 & 15.08 & 15.33 & 9.96 & 9.64 & 13.29 & 14.39 & 16.91 & 11.22 & 11.06 & 11.06 & 14.22 \\
\hline 0.31 & 0.20 & 0.22 & 0.21 & 0.26 & 0.15 & 0.30 & 0.24 & 0.13 & 0.16 & 0.31 & 0.22 & 0.28 \\
\hline 28.57 & 28.25 & 10.44 & 5.32 & 22.59 & 15.90 & 12.51 & 11.73 & 19.89 & 28.23 & 27.90 & 28.59 & 25.68 \\
\hline 3.68 & 3.43 & 17.63 & 10.97 & 10.01 & 17.96 & 17.52 & 17.37 & 16.54 & 3.76 & 4.11 & 3.39 & 4.37 \\
\hline 0.03 & 0.005 & 0.27 & 1.13 & 0.05 & 0.23 & 0.31 & 0.19 & 0.23 & 0.02 & 0.03 & 0.29 & 0.07 \\
\hline 0.02 & 0.00 & 0.00 & 0.31 & 0.00 & 0.00 & 0.00 & 0.00 & 0.02 & 0.01 & 0.00 & 0.00 & 0.00 \\
\hline 100.13 & 100.64 & 100.21 & 98.96 & 99.87 & 100.14 & 99.83 & 99.24 & 99.40 & 100.06 & 100.05 & 101.20 & 101.58 \\
\hline 1.967 & 1.971 & 1.705 & 1.873 & 1.948 & 1.843 & 1.774 & 1.753 & 1.697 & 1.964 & 1.964 & 1.980 & 1.931 \\
\hline 0.001 & 0.002 & 0.028 & 0.016 & 0.045 & 0.016 & 0.023 & 0.022 & 0.034 & 0.001 & 0.002 & 0.000 & 0.002 \\
\hline 0.047 & 0.048 & 0.470 & 0.636 & 0.120 & 0.244 & 0.350 & 0.383 & 0.469 & 0.048 & 0.050 & 0.046 & 0.108 \\
\hline 0.007 & 0.007 & 0.000 & 0.000 & 0.002 & 0.002 & 0.000 & 0.000 & 0.000 & 0.007 & 0.009 & 0.003 & 0.003 \\
\hline 0.322 & 0.343 & 0.477 & 0.475 & 0.301 & 0.297 & 0.418 & 0.458 & 0.544 & 0.334 & 0.330 & 0.324 & 0.424 \\
\hline 0.009 & 0.006 & 0.007 & 0.006 & 0.008 & 0.005 & 0.010 & 0.008 & 0.004 & 0.005 & 0.009 & 0.007 & 0.008 \\
\hline 1.509 & 1.491 & 0.589 & 0.294 & 1.215 & 0.866 & 0.701 & 0.666 & 0.567 & 1.496 & 1.483 & 1.495 & 1.364 \\
\hline 0.140 & 0.130 & 0.715 & 0.436 & 0.387 & 0.708 & 0.706 & 0.709 & 0.681 & 0.143 & 0.157 & 0.127 & 0.167 \\
\hline 0.002 & 0.004 & 0.020 & 0.081 & 0.004 & 0.017 & 0.022 & 0.014 & 0.017 & 0.002 & 0.002 & 0.020 & 0.005 \\
\hline 0.001 & 0.000 & 0.000 & 0.015 & 0.000 & 0.000 & 0.000 & 0.000 & 0.001 & 0.000 & 0.000 & 0.000 & 0.000 \\
\hline 7.100 & 6.600 & 40.000 & 36.000 & 20.300 & 37.700 & 38.500 & 38.500 & 37.900 & 7.200 & 7.900 & 8.500 & 8.500 \\
\hline 76.200 & 75.700 & 32.900 & 24.300 & 63.600 & 46.200 & 38.200 & 36.200 & 31.600 & 75.700 & 74.900 & 76.500 & 69.500 \\
\hline 16.700 & 17.700 & 27.100 & 40.700 & 16.100 & 16.100 & 23.300 & 25.300 & 30.500 & 17.100 & 17.100 & 17.000 & 22.000 \\
\hline
\end{tabular}




\section{H. BOUGAULT ET AL.}

Table 8. Hole 458: Sample 458-44-1, glass composition of bronzite andesite.

\begin{tabular}{lrrrrrrrrrr}
\hline Analysis & \multicolumn{1}{c}{51} & \multicolumn{1}{c}{52} & \multicolumn{1}{c}{53} & \multicolumn{1}{c}{54} & \multicolumn{1}{c}{55} & \multicolumn{1}{c}{56} & \multicolumn{1}{c}{57} & 58 & 59 & 60 \\
\hline $\mathrm{SiO}_{2}$ & 61.72 & 61.80 & 61.30 & 61.68 & 60.16 & 60.30 & 60.53 & 61.34 & 61.14 & 52.83 \\
$\mathrm{TiO}_{2}$ & 0.33 & 0.31 & 0.35 & 0.36 & 0.28 & 0.34 & 0.39 & 0.37 & 0.37 & 0.24 \\
$\mathrm{Al}_{2} \mathrm{O}_{3}$ & 18.86 & 18.36 & 18.25 & 18.53 & 17.75 & 18.03 & 18.05 & 18.12 & 17.96 & 3.26 \\
$\mathrm{Cr}_{2} \mathrm{O}_{3}$ & 0.00 & 0.05 & 0.01 & 0.00 & 0.00 & 0.00 & 0.14 & 0.00 & 0.01 & 0.16 \\
$\mathrm{FeO}^{*}$ & 4.26 & 4.89 & 4.98 & 4.43 & 5.53 & 5.51 & 5.29 & 5.04 & 4.81 & 10.97 \\
$\mathrm{MnO}$ & 0.01 & 0.15 & 0.01 & 0.01 & 0.04 & 0.10 & 0.14 & 0.00 & 0.03 & 0.25 \\
$\mathrm{MgO}$ & 0.64 & 0.52 & 0.86 & 0.75 & 1.29 & 1.02 & 0.96 & 0.91 & 0.82 & 21.11 \\
$\mathrm{CaO}$ & 5.24 & 5.13 & 5.25 & 5.19 & 5.71 & 5.71 & 5.52 & 5.54 & 5.31 & 9.82 \\
$\mathrm{Na}_{2} \mathrm{O}$ & 2.53 & 2.63 & 2.53 & 2.64 & 2.64 & 1.93 & 2.51 & 2.21 & 2.65 & 0.00 \\
$\mathrm{~K}_{2} \mathrm{O}$ & 0.56 & 0.56 & 0.54 & 0.54 & 0.50 & 0.58 & 0.63 & 0.50 & 0.59 & 0.01 \\
$\mathrm{P}_{2} \mathrm{O} 5$ & 0.11 & 0.29 & 0.11 & 0.20 & 0.14 & 0.09 & 0.11 & 0.17 & 0.13 & 0.00 \\
$\mathrm{Total}$ & 94.26 & 94.69 & 94.19 & 94.33 & 94.04 & 93.61 & 94.27 & 94.20 & 93.82 & 98.65 \\
$\mathrm{Q}$ & 33.23 & 32.83 & 31.90 & 32.65 & 28.01 & 32.66 & 29.73 & 33.49 & 31.05 & \\
$\mathrm{Or}$ & 3.50 & 3.49 & 3.38 & 3.38 & 3.14 & 3.65 & 3.95 & 3.13 & 3.71 & \\
ab & 22.67 & 23.46 & 22.68 & 23.63 & 23.70 & 17.41 & 22.52 & 19.81 & 23.85 & \\
an & 26.77 & 24.84 & 26.84 & 25.86 & 29.09 & 29.58 & 28.28 & 27.95 & 27.13 & \\
co & 5.12 & 5.06 & 4.48 & 4.92 & 3.00 & 4.33 & 3.68 & 4.54 & 3.86 & \\
en & 1.69 & 1.37 & 2.27 & 1.98 & 3.41 & 2.71 & 2.54 & 2.40 & 2.17 & \\
fs & 3.79 & 5.32 & 5.16 & 4.06 & 6.44 & 6.42 & 5.95 & 5.22 & 4.85 & \\
$\mathrm{mt}$ & 2.30 & 2.29 & 2.31 & 2.30 & 2.31 & 2.32 & 2.31 & 2.31 & 2.31 & \\
il & 0.66 & 0.62 & 0.70 & 0.72 & 0.56 & 0.69 & 0.79 & 0.74 & 0.75 & \\
ap & 0.28 & 0.73 & 0.28 & 0.50 & 0.35 & 0.23 & 0.28 & 0.43 & 0.33 & \\
$\mathrm{~S} .1$. & 8.00 & 5.94 & 9.64 & 8.96 & 12.89 & 11.16 & 10.07 & 10.51 & 9.21 & \\
$\mathrm{D} . \mathrm{L}$ & 59.40 & 59.79 & 57.97 & 59.66 & 54.85 & 53.73 & 56.20 & 56.43 & 58.61 & \\
\hline
\end{tabular}

Note: 51 -54: glassy matrix. 55-59: glass composition at 25, 20,15, 10, and 5 am from a pyroxene microlite $(60)$.

Table 9. Hole 458: Pyroxene analyses from basaltic andesites and andesites. Normalized to 6 oxygens.

\begin{tabular}{|c|c|c|c|c|c|c|c|c|c|c|c|c|c|c|c|c|c|c|c|c|}
\hline \multirow{2}{*}{$\begin{array}{l}\text { Sample } \\
\text { Analysis }\end{array}$} & \multicolumn{5}{|c|}{$458-29 \cdot 2$} & \multicolumn{5}{|c|}{$458-33-2$} & \multicolumn{5}{|c|}{$458-37-2$} & \multicolumn{5}{|c|}{$458-47-1$} \\
\hline & 61 & 62 & 63 & 64 & 65 & 66 & 67 & 68 & 69 & 70 & 71 & 72 & 73 & 74 & 75 & 76 & 77 & 78 & 79 & 80 \\
\hline $\mathrm{SiO}_{2}$ & 54.04 & 54.15 & 53.31 & 54.55 & 53.51 & 53.90 & 54.58 & 54.13 & 51.30 & 52.28 & 54.64 & $\$ 4.70$ & 54.51 & 54.81 & 52.63 & 52.06 & 52.67 & 52,73 & 51.68 & 49.60 \\
\hline $\mathrm{TiO}_{2}$ & 0.17 & 0.13 & 0.13 & 0.05 & 0.10 & 0.07 & 0.02 & 0.04 & 0.26 & 0.16 & 0.13 & 0.07 & 0.00 & 0.00 & 0.10 & 0.32 & 0.25 & 0.41 & 0.35 & 0.84 \\
\hline $\mathrm{Al}_{2} \mathrm{O}_{3}$ & 2.85 & 2.32 & 2.17 & 2.59 & 3.10 & 1.69 & 1.60 & 2.17 & 2.81 & 2.67 & 2.06 & 2.06 & 2.25 & 1.68 & 1.93 & 2.17 & 1.90 & 2.03 & 1.47 & 2.90 \\
\hline $\mathrm{Cr}_{2} \mathrm{O}_{3}$ & 0.31 & 0.00 & 0.00 & 0.60 & 0.04 & 0.45 & 0.26 & 0.13 & 0.00 & 0.00 & 0.64 & 0.00 & 0.34 & 0.15 & 0.06 & 0.00 & 0.00 & 0.00 & 0.03 & 0.00 \\
\hline FeÖ- & 7.32 & 11.39 & 13.77 & 5.58 & 6.19 & 4.89 & 5.40 & 6.01 & 14.80 & 10.09 & 5.72 & 5.56 & 5.36 & 5.35 & 14.34 & 10.90 & 10.26 & 10.66 & 16.52 & 15.68 \\
\hline $\mathrm{MnO}$ & 0.10 & 0.17 & 0.26 & 0.00 & 0.13 & 0.08 & 0.25 & 0.19 & 0.30 & 0.11 & 0.00 & 0.08 & 0.19 & 0.13 & 0.45 & 0.29 & 0.29 & 0.25 & 0.50 & 0.24 \\
\hline $\mathrm{MgO}$ & 18.62 & 19.18 & 17.79 & 18.94 & 17.89 & 18.32 & 18.44 & 18.50 & 12.99 & 15.34 & 18.90 & 18.45 & 18.97 & 18.75 & 16.37 & 15.55 & 15.51 & 15,16 & 14.69 & 11.94 \\
\hline $\mathrm{CaO}$ & 16.66 & 12.82 & 12.28 & 17.32 & 19.00 & 19.56 & 19.16 & 18.65 & 16.85 & 18.38 & 18.50 & 19.02 & 17.98 & 18.90 & 13.71 & 17.46 & 18.20 & 18.37 & 13.54 & 17.02 \\
\hline $\mathrm{Na}_{2} \mathrm{O}$ & 0.08 & 0.05 & 0.16 & 0.20 & 0.13 & 0.09 & 0.14 & 0.11 & 0.18 & 0.15 & 0.11 & 0.12 & 0.11 & 0.05 & 1.21 & 0.23 & 0.22 & 0.25 & 0.18 & 0.29 \\
\hline $\mathrm{K}_{2} \mathrm{O}$ & 0.00 & 0.00 & 0.00 & 0.00 & 0.00 & 0.00 & 0.05 & 0.00 & 0.00 & 0.00 & 0.00 & 0.00 & 0.00 & 0.00 & 0.00 & 0.00 & 0.00 & 0.00 & 0.04 & 0.00 \\
\hline Total & 100.15 & 100.21 & 99.87 & 99.83 & 100.09 & 99.05 & 99.90 & 99.93 & 99,49 & 99.18 & 100.70 & 100,06 & 99.71 & 99.82 & 100,80 & 98.98 & 99.30 & 99.86 & 99.00 & 98.51 \\
\hline Si & 1.951 & 1.968 & 1.966 & 1.962 & 1.940 & 1.962 & 1.973 & 1.961 & 1.937 & 1.943 & 1.955 & 1.8713 & 1.966 & 1.977 & 1.948 & 1.944 & 1.959 & 1.953 & 1.963 & 1.908 \\
\hline $\mathrm{Ti}$ & 0.005 & 0.004 & 0.004 & 0.001 & 0.003 & 0.002 & 0.001 & 0.001 & 0.007 & 0.005 & 0.004 & 0.002 & 0.000 & 0.000 & 0.003 & 0.009 & 0.007 & 0.011 & 0.010 & 0.024 \\
\hline Al & 0.121 & 0.100 & 0.094 & 0.110 & 0.967 & 0.072 & 0.068 & 0.093 & 0.125 & 0.117 & 0.087 & 0.088 & 0.096 & 0.072 & 0.084 & 0.095 & 0.083 & 0.089 & 0.066 & 0.131 \\
\hline $\mathrm{Cr}$ & 0.009 & 0.000 & 0.000 & 0.017 & 0.001 & 0.013 & 0.007 & 0.004 & 0.000 & 0.000 & 0.018 & 0.000 & 0.010 & 0.004 & 0.002 & 0.000 & 0.000 & 0.000 & 0.001 & 0.000 \\
\hline $\mathrm{Fe}$ & 0.221 & 0.346 & 0.425 & 0.168 & 0.188 & 0.145 & 0.163 & 0.182 & 0.467 & 0.314 & 0.173 & 0.168 & 0.162 & 0.161 & 0.444 & 0.340 & 0.319 & 0.330 & 0.525 & 0.005 \\
\hline $\mathrm{Mn}$ & 0.003 & 0.005 & 0.008 & 0.000 & 0.004 & 0.002 & 0.008 & 0.006 & 0.010 & 0.004 & 0.000 & 0.002 & 0.006 & 0.004 & 0.014 & 0.009 & 0.009 & 0.008 & 0.016 & 0.008 \\
\hline $\mathrm{Mg}$ & 1.002 & 1.040 & 0.978 & 1.015 & 0.967 & 0.994 & 0.994 & 0.999 & 0.731 & 0.850 & 1.008 & 0.991 & 1.020 & 1.008 & 0.903 & 0.866 & 0.860 & 0.837 & 0.832 & 0.685 \\
\hline $\mathrm{Ca}$ & 0.645 & 0.499 & 0.485 & 0.667 & 0.738 & 0.763 & 0.742 & 0.724 & 0.682 & 0.732 & 0.709 & 0.734 & 0.695 & 0.731 & 0.544 & 0.698 & 0.725 & 0.729 & 0.551 & 0.702 \\
\hline $\mathrm{Na}$ & 0.006 & 0.004 & 0.012 & 0.014 & 0.010 & 0.007 & 0.010 & 0.08 & 0.013 & 0.011 & 0.008 & 0.009 & 0.008 & 0.004 & 0.087 & 0.017 & 0.016 & 0.018 & 0.014 & 0.022 \\
\hline K & 0.000 & 0.000 & 0.000 & 0.000 & 0.000 & 0.000 & 0.02 & 0.000 & 0.000 & 0.000 & 0.000 & 0.000 & 0.000 & 0.000 & 0.000 & 0.000 & 0.000 & 0.000 & 0.002 & 0.000 \\
\hline $\mathrm{Ca}$ & 34.5 & 26.4 & 25.6 & 36.1 & 38.9 & 40.0 & 38.9 & 37.9 & 36.1 & 38.5 & 37.5 & 38.7 & 36.9 & 38.3 & 28.6 & 36.5 & 37.9 & 38.3 & 28.6 & 36.9 \\
\hline $\mathrm{Mg}$ & 53.5 & 55.0 & 51.6 & 54.9 & 51.0 & 52.1 & 52.1 & 52.3 & 38.7 & 44.8 & 53.4 & 52.3 & 54.2 & 53.0 & 47.4 & 45.2 & 44.9 & 44.0 & 43.3 & 36.1 \\
\hline $\mathrm{Fe}+\mathrm{Mn}$ & 12.0 & 18.6 & 22.8 & 9.1 & 10.1 & 7.9 & 9.0 & 9.8 & 25.2 & 16.7 & 9.1 & 9.0 & 8.9 & 8.7 & 24.0 & 18.3 & 17.2 & 17.7 & 28.1 & 27.0 \\
\hline
\end{tabular}

Note: Phenocrysis: cores: $61,62,66,67,68,71,72,76,77$; rims: $63,69,70,73,78$; matrix pyroxenes: $64,65,74,75,79,80$.

Table 10. Hole 458: Plagioclase analyses.

\begin{tabular}{|c|c|c|c|c|c|c|c|c|c|c|}
\hline \multirow{2}{*}{$\begin{array}{l}\text { Sample } \\
\text { Analysis }\end{array}$} & \multicolumn{3}{|c|}{$458-29-2$} & \multicolumn{2}{|c|}{$458-33-2$} & \multicolumn{5}{|c|}{$438-47-1$} \\
\hline & 81 & 82 & 83 & 84 & 85 & 86 & 87 & 88 & 89 & 90 \\
\hline $\mathrm{SiO}_{2}$ & 53.98 & 52.82 & 52.48 & 53.05 & 54.33 & 50.29 & 50.27 & 53.86 & 51.64 & 51.43 \\
\hline $\mathrm{TiO}_{2}^{2}$ & 0.00 & 0.00 & 0.00 & 0.07 & 0.04 & 0.00 & 0.00 & 0.01 & 0.03 & 0.01 \\
\hline $\mathrm{Al}_{2} \mathrm{O}_{3}$ & 29.32 & 30.59 & 30.99 & 29.40 & 28.64 & 31.78 & 31.5 & 29.52 & 31.07 & 31.08 \\
\hline $\mathrm{Cr}_{2} \mathrm{O}_{3}$ & 0.00 & 0.00 & 0.00 & 0.00 & 0.00 & 0.00 & 0.09 & 0.00 & 0.00 & 0.00 \\
\hline $\mathrm{FeO}^{*}$ & 1.24 & 0.89 & 0.80 & 076 & 1.11 & 0.62 & 0.61 & 1.05 & 0.71 & 0.93 \\
\hline $\mathrm{MnO}$ & 0.00 & 0.00 & 0.04 & 0.00 & 0.02 & 0.00 & 0.04 & 0.00 & 0.00 & 0.00 \\
\hline $\mathrm{MgO}$ & 0.08 & 0.30 & 0.22 & 0.06 & 0.20 & 0.24 & 0.14 & 0.06 & 0.14 & 0.16 \\
\hline $\mathrm{CaO}$ & 12.31 & 13.64 & 13.78 & 12.14 & 11.37 & 14.76 & 14.91 & 11.75 & 14.05 & 13.98 \\
\hline $\mathrm{Na}_{2} \mathrm{O}$ & 3.75 & 3.03 & 3.17 & 3.92 & 4.45 & 2.38 & 2.48 & 4.11 & 2.86 & 3.00 \\
\hline $\mathrm{K}_{2} \mathrm{O}$ & 0.12 & 0.00 & 0.05 & 0.61 & 0.19 & 0.04 & 0.05 & 0.08 & 0.03 & 0.03 \\
\hline Total & 100.80 & 101.27 & 101.53 & 99.41 & 100.35 & 100.11 & 100.09 & 100.44 & 100.53 & 100.62 \\
\hline $\mathrm{Ca}$ & 640 & 713 & 70.4 & 630 & 579 & $77 ?$ & 690 & 609 & 730 & 71.9 \\
\hline $\mathrm{Na}$ & 35.3 & 28.7 & 29.3 & 36.9 & 41.0 & 22.5 & 30.4 & 38.5 & 26.9 & 28.0 \\
\hline K & 0.7 & 0.0 & 0.3 & 0.1 & 1.1 & 0.3 & 0.6 & 0.6 & 0.1 & 0.1 \\
\hline
\end{tabular}

Note: Phenocrysts - cores: $81,86,87 ;$ rims: 88 ; matrix plagioclases: $82,83,84,85,89,90$. 
Table 11A. Holes 456A, 456, and 459: Major elements and C.I.P.W. norms of lavas.

\begin{tabular}{|c|c|c|c|c|c|c|c|c|c|c|c|c|}
\hline $\begin{array}{l}\text { Sample } \\
\text { (interval in } \mathrm{cm} \text { ) }\end{array}$ & $\begin{array}{c}456 \mathrm{~A}-12-1 \\
62-64\end{array}$ & $\begin{array}{c}456 \mathrm{~A}-14-1 \\
25-27\end{array}$ & $\begin{array}{c}456-16-2 \\
98-100\end{array}$ & $\begin{array}{c}456-18-1 \\
25-27\end{array}$ & $\begin{array}{c}456-19-1 \\
12-15\end{array}$ & $\begin{array}{c}459 \mathrm{~B}-60-1, \\
48-51\end{array}$ & $\begin{array}{c}459 \mathrm{~B}-60-2 \\
87-90\end{array}$ & $\begin{array}{c}459 \mathrm{~B}-61-2, \\
12-16\end{array}$ & $\begin{array}{c}459 \mathrm{~B}-66-2 \\
92-95\end{array}$ & $\begin{array}{c}459 \mathrm{~B}-69-1 \\
81-84\end{array}$ & $\begin{array}{c}\text { 459B-72-1, } \\
94-97\end{array}$ & $\begin{array}{c}\text { 459B-73-2, } \\
13-17\end{array}$ \\
\hline $\mathrm{SiO}_{2}$ & 49.86 & 50.53 & 49.50 & 49.79 & 50.77 & 51.04 & 53.43 & 53.74 & 52.06 & 55.10 & 54.01 & 53.28 \\
\hline $\begin{array}{l}\mathrm{Al}_{2} \mathrm{O}_{3} \\
\mathrm{FeO}\end{array}$ & 15.68 & 16.21 & 15.22 & 17.02 & 15.68 & 17.20 & 15.42 & 15.62 & 16.62 & 16.77 & 16.22 & 17.48 \\
\hline $\mathrm{Fe}_{2} \mathrm{O}_{3}$ & 10.12 & 8.91 & 10.16 & 9.52 & 9.84 & 11.25 & 10.20 & 10.35 & 12.61 & 9.78 & 12.03 & 12.37 \\
\hline MnO & 0.158 & 0.148 & 0.29 & 0.166 & 0.118 & 0.118 & 0.136 & 0.147 & 0.166 & 0.110 & 0.113 & 0.120 \\
\hline $\mathrm{MgO}$ & 6.92 & 7.14 & 7.45 & 5.63 & 6.20 & 5.06 & 6.47 & 6.16 & 3.86 & 3.78 & 3.45 & 3.83 \\
\hline $\mathrm{CaO}$ & 11.99 & 11.86 & 12.59 & 12.75 & 12.40 & 11.71 & 10.98 & 11.03 & 8.96 & 9.16 & 7.75 & 7.36 \\
\hline $\mathrm{Na}_{2} \mathrm{O}$ & 2.41 & 2.67 & 2.40 & 2.76 & 2.60 & 2.67 & 2.49 & 2.49 & 3.54 & 3.47 & 3.49 & 3.61 \\
\hline $\mathrm{K}_{2} \mathrm{O}$ & 0.43 & 0.37 & 0.04 & 0.33 & 0.28 & 0.45 & 0.34 & 0.35 & 0.66 & 0.45 & 1.16 & 0.42 \\
\hline $\mathrm{TiO}_{2}$ & 1.23 & 1.15 & 1.19 & 1.21 & 1.14 & 0.74 & 0.67 & 0.70 & 1.07 & 0.78 & 1.02 & 1.05 \\
\hline $\mathrm{P}_{2} \mathrm{O}_{5}$ & 0.16 & 0.13 & 0.14 & 0.15 & 0.13 & 0.11 & 0.09 & 0.09 & 0.12 & 0.11 & 0.14 & 0.14 \\
\hline Total & 98.96 & 99.12 & 98.98 & 99.28 & 99.16 & 100.35 & 100.23 & 100.68 & 99.67 & 99.51 & 99.38 & 99.66 \\
\hline $\begin{array}{l}\text { Loss on } \\
\text { Ignition } \\
110^{\circ} \mathrm{C}\end{array}$ & 0.71 & 0.52 & 1.88 & 1.56 & 2.18 & 1.70 & 1.17 & 0.86 & 1.69 & 0.80 & 1.31 & 3.04 \\
\hline $\begin{array}{l}\text { Loss on } \\
\text { lgnition } \\
1050^{\circ} \mathrm{C}\end{array}$ & 0.77 & 0.50 & 7,09 & 1.67 & 1.45 & 1.33 & 1.02 & 0.54 & 1.28 & 0.69 & 1.25 & 2.30 \\
\hline Q & & & & & & 0.30 & 4.36 & 4.81 & 0.71 & 6.60 & 3.99 & 3.89 \\
\hline or & 2.59 & 2.22 & 0.24 & 1.98 & 1.78 & 2.68 & 2.02 & 2.07 & 3.96 & 2.69 & 6.97 & 2.52 \\
\hline$a b$ & 20.78 & 22.95 & 21.02 & 23.69 & 23.65 & 22.72 & 21.20 & 21.10 & 30.38 & 29.74 & 30.02 & 30.97 \\
\hline $\begin{array}{l}\text { an } \\
\text { ne }\end{array}$ & 31.29 & 31.67 & 34.07 & 33.57 & 31.14 & 33.83 & 30.09 & 30.48 & 27.92 & 29.24 & 25.60 & 30.69 \\
\hline wo & 11.80 & 11.38 & 12.18 & 12.37 & 13.68 & 9.97 & 10.07 & 9.92 & 6.84 & 6.71 & 5.25 & 2.26 \\
\hline di en & 6.81 & 7.02 & 7.23 & 6.85 & 7.92 & 4.69 & 5.51 & 5.29 & 2.64 & 3.02 & 1.97 & 0.88 \\
\hline fs & 4.46 & 3.71 & 4.33 & 5.05 & 5.13 & 5.17 & 4.20 & 4.31 & 4.30 & 3.65 & 3.37 & 1.41 \\
\hline en & 9.66 & 9.69 & 3.46 & 4.78 & 3.51 & 7.99 & 10.70 & 10.08 & 7.11 & 6.51 & 6.76 & 8.79 \\
\hline fs & 6.32 & 5.12 & 2.07 & 3.53 & 2.28 & 8.80 & 8.17 & 8.22 & 11.60 & 7.87 & 11.56 & 14.03 \\
\hline fo & 0.77 & 0.96 & 6.31 & 1.82 & 3.46 & & & & & & & \\
\hline $\mathrm{fa}$ & 0.55 & 0.56 & 4.16 & 1.48 & 2.47 & & & & & & & \\
\hline $\mathrm{mt}$ & 2.22 & 2.21 & 2.25 & 2.21 & 2.34 & 2.19 & 2.19 & 2.18 & 2.21 & 2.20 & 2.21 & 2.21 \\
\hline ii & 2.38 & 2.22 & 2.34 & 2.33 & 2.33 & 1.41 & 1.28 & 1.33 & 2.06 & 1.50 & 1.97 & 2.02 \\
\hline ap & 0.39 & 0.31 & 0.34 & 0.36 & 0.33 & 0.26 & 0.21 & 0.21 & 0.29 & 0.26 & 0.34 & 0.34 \\
\hline S.I. & 36.37 & 38.91 & 39.44 & 32.25 & 35.10 & 27.46 & 34.75 & 33.36 & 19.71 & 22.75 & 18.12 & 20.04 \\
\hline D.I. & 23.37 & 25.18 & 21.26 & 25.67 & 25.43 & 25.70 & 27.58 & 27.99 & 35.05 & 39.04 & 40.98 & 37.38 \\
\hline
\end{tabular}

Table 11B. Hole 453: Major elements (ppm).

\begin{tabular}{lcccc}
\hline $\begin{array}{l}\text { Sample } \\
\text { (interval in cm) }\end{array}$ & $\begin{array}{c}453-53-3, \\
44-47\end{array}$ & $\begin{array}{c}453-53-5, \\
77-88\end{array}$ & $\begin{array}{c}453-55-1, \\
36-48\end{array}$ & $\begin{array}{r}453-55-4, \\
118-123\end{array}$ \\
\hline $\mathrm{SiO}_{2}$ & 44.64 & 45.35 & 45.35 & 43.60 \\
$\mathrm{Al}_{2} \mathrm{O}_{3}$ & 19.86 & 19.64 & 19.38 & 28.99 \\
$\mathrm{FeO}^{\mathrm{Fe}} \mathrm{O}_{3}$ & 7.36 & 5.87 & 5.75 & 6.32 \\
$\mathrm{MnO}$ & 0.118 & 0.101 & & 0.113 \\
$\mathrm{MgO}$ & 10.91 & 9.03 & 8.90 & 6.64 \\
$\mathrm{CaO}$ & 16.13 & 18.25 & 18.59 & 13.38 \\
$\mathrm{Na}_{2} \mathrm{O}$ & 0.64 & 0.52 & 0.65 & 0.71 \\
$\mathrm{~K}_{2} \mathrm{O}$ & 0.20 & 0.11 & 0.23 & 0.62 \\
$\mathrm{TiO}_{2}$ & 0.14 & 0.17 & 0.23 & 0.05 \\
$\mathrm{P}_{2} \mathrm{O}_{5}$ & 0.04 & 0.03 & 0.03 & 0.03 \\
$\mathrm{Total}^{20}$ & 99.94 & 99.07 & 99.11 & 100.45 \\
Loss on & 0.32 & 0.23 & 0.32 & 0.34 \\
$\mathrm{Ignition}_{110^{\circ} \mathrm{C}}$ & & & & \\
Loss on & 2.02 & 1.98 & 2.07 & 2.94 \\
Ignition & & & & \\
$1050^{\circ} \mathrm{C}$ & & & & \\
\hline
\end{tabular}


Table 12. Hole 453: Trace elements.

\begin{tabular}{|c|c|c|c|c|c|c|c|c|c|c|c|c|}
\hline \multirow{2}{*}{$\begin{array}{c}\text { Sample } \\
\text { (interval in } \mathrm{cm} \text { ) }\end{array}$} & \multirow{2}{*}{$\begin{array}{c}\mathrm{Sc} \\
\mathrm{NAA}\end{array}$} & \multirow{2}{*}{$\begin{array}{c}\mathrm{Ti} \\
\mathrm{XRF}\end{array}$} & \multirow{2}{*}{$\begin{array}{c}\text { V } \\
\text { XRF }\end{array}$} & \multirow{2}{*}{$\begin{array}{c}\mathrm{Cr} \\
\mathrm{XRF}\end{array}$} & \multirow{2}{*}{$\begin{array}{l}\text { Mn } \\
\text { XRF }\end{array}$} & \multirow{2}{*}{$\begin{array}{c}\mathrm{Fe} \\
\mathrm{XRF}\end{array}$} & \multicolumn{2}{|c|}{ Co } & \multicolumn{2}{|c|}{$\mathrm{Ni}$} & \multirow{2}{*}{$\underset{\mathrm{XRF}}{\mathrm{Zn}}$} & \multirow{2}{*}{$\begin{array}{c}\mathrm{Rb} \\
\mathrm{XRF}\end{array}$} \\
\hline & & & & & & & $\mathrm{XRF}$ & NAA & $\mathrm{XRF}$ & NAA & & \\
\hline $453-53-3,44-47$ & 383 & 840 & 98 & 88 & 914 & 51520 & 48 & 55 & 58 & 57 & 14 & 1.85 \\
\hline $453-53-5,77-88$ & 48 & 1020 & 125 & 103 & 782 & 41090 & 36 & 38 & 40 & 40 & 7 & 0.19 \\
\hline $453-55-1,36-48$ & 6.07 & 1380 & 188 & 315 & & 40250 & 27 & 31 & 31 & 29 & 4 & 0.87 \\
\hline $453-55-4,118-123$ & 1.50 & 300 & 12 & 0 & 875 & 44240 & 73 & 75 & 25 & 30 & 61 & 3.97 \\
\hline
\end{tabular}

Note: $\mathrm{XRF}=\mathrm{X}$-ray fluorescence analysis, NAA $=$ neutron activation analysis.

Table 13. Hole 454: Trace elements (ppm).

\begin{tabular}{|c|c|c|c|c|c|c|c|c|c|c|c|c|c|}
\hline \multirow{2}{*}{$\begin{array}{c}\text { Sample } \\
\text { (interval in } \mathrm{cm} \text { ) }\end{array}$} & \multirow{2}{*}{$\begin{array}{c}\mathrm{Sc} \\
\mathrm{NAA}\end{array}$} & \multirow{2}{*}{$\begin{array}{c}\mathrm{Ti} \\
\mathrm{XRF}\end{array}$} & \multirow{2}{*}{$\begin{array}{c}\mathrm{V} \\
\mathrm{XRF}\end{array}$} & \multirow{2}{*}{$\begin{array}{l}\mathrm{Cr} \\
\mathrm{XRF}\end{array}$} & \multirow{2}{*}{$\begin{array}{l}\mathrm{Mn} \\
\text { XRF }\end{array}$} & \multirow{2}{*}{$\begin{array}{c}\mathrm{Fe} \\
\mathrm{XRF}\end{array}$} & \multicolumn{2}{|c|}{ Co } & \multicolumn{2}{|c|}{$\mathrm{Ni}$} & \multirow{2}{*}{$\underset{\mathrm{XRF}}{\mathrm{Zn}}$} & \multirow{2}{*}{$\begin{array}{c}\mathrm{Rb} \\
\mathrm{XRF}\end{array}$} & \multirow{2}{*}{$\begin{array}{c}\mathrm{Sr} \\
\mathrm{XRF}\end{array}$} \\
\hline & & & & & & & XRF & NAA & XRF & NAA & & & \\
\hline $454-5-1,38-40$ & 30.6 & 6000 & 236 & 260 & 968 & 56840 & & $\begin{array}{l}29 \\
31.7\end{array}$ & & $\begin{array}{l}75 \\
79\end{array}$ & 54 & $\begin{array}{l}5.34 \\
5.9\end{array}$ & 176 \\
\hline $454-5-3,52-54$ & 29.1 & 5760 & 207 & 248 & 867 & 53900 & 32 & 33.9 & 106 & 112 & 42 & $\begin{array}{l}2.16 \\
3.2\end{array}$ & 1000 \\
\hline $454-5-4,50-52$ & 26.7 & 4980 & 186 & 770 & 898 & 61180 & 48 & 51.9 & 359 & 412 & 44 & 1.74 & 145 \\
\hline $454-6, C C, 16-18$ & 30 & 5640 & 219 & 270 & 898 & 58450 & 35 & 36 & 114 & 117 & 48 & 0.73 & 152 \\
\hline $454-8-1,35-37$ & 29 & 5340 & 230 & 523 & 883 & 61390 & 42 & 44 & 229 & 247 & 50 & 3.27 & 146 \\
\hline $454-10-1,58-60$ & 32 & 6000 & 265 & 231 & 1069 & 57960 & 30 & 32.4 & 76 & 84 & 48 & 2.98 & 202 \\
\hline $454-11-1,78-80$ & 31 & 5760 & 234 & 223 & 968 & 57960 & 32 & 34 & 109 & 119 & 52 & 2.40 & 202 \\
\hline $\begin{array}{l}454-11-2,41-43 \\
454-12-1,88-90\end{array}$ & 30.8 & $\begin{array}{l}6360 \\
6120\end{array}$ & $\begin{array}{l}265 \\
279\end{array}$ & $\begin{array}{l}222 \\
218\end{array}$ & $\begin{array}{r}1161 \\
929\end{array}$ & $\begin{array}{l}65100 \\
57120\end{array}$ & $\begin{array}{l}29 \\
30\end{array}$ & 31.7 & $\begin{array}{l}57 \\
97\end{array}$ & 103 & $\begin{array}{l}53 \\
51\end{array}$ & $\begin{array}{r}4.39 \\
5.56 \\
3.7\end{array}$ & $\begin{array}{l}122 \\
211\end{array}$ \\
\hline $454-14-1,12-14$ & 30 & 7380 & 250 & 245 & 1146 & 62860 & 32 & 35 & 106 & 127 & 56 & 7.90 & 169 \\
\hline $454-16-1,138-141$ & 28.4 & 6660 & 257 & 487 & 1216 & 66220 & 40 & 42 & 223 & 261 & & 7.27 & 164 \\
\hline $\begin{array}{l}\text { Average } \\
\text { Dispersion }\end{array}$ & & $\begin{array}{r}5964 \\
\pm 670\end{array}$ & $\begin{array}{r}236 \\
\pm 20\end{array}$ & & & & & & & & & & \\
\hline
\end{tabular}

Note: $\mathrm{XRF}=\mathrm{X}$-ray fluorescence analysis, NAA $=$ neutron activation analysis.

Table 14. Holes 456 and 456A: Trace elements (ppm).

\begin{tabular}{|c|c|c|c|c|c|c|c|c|c|c|c|c|}
\hline \multirow{2}{*}{$\begin{array}{c}\text { Sample } \\
\text { (interval in cm) }\end{array}$} & \multirow{2}{*}{$\begin{array}{c}\mathrm{Sc} \\
\mathrm{NAA}\end{array}$} & \multirow{2}{*}{$\begin{array}{c}\mathrm{Ti} \\
\mathrm{XRF}\end{array}$} & \multirow{2}{*}{$\begin{array}{c}\mathrm{V} \\
\mathrm{XRF}\end{array}$} & \multirow{2}{*}{$\begin{array}{c}\mathrm{Cr} \\
\mathrm{XRF}\end{array}$} & \multirow{2}{*}{$\begin{array}{l}\mathrm{Mn} \\
\mathrm{XRF}\end{array}$} & \multirow{2}{*}{$\begin{array}{c}\mathrm{Fe} \\
\mathrm{XRF}\end{array}$} & \multicolumn{2}{|c|}{$\mathrm{Co}$} & \multicolumn{2}{|c|}{$\mathrm{Ni}$} & \multirow{2}{*}{$\underset{\mathrm{XRF}}{\mathrm{Zn}}$} & \multirow{2}{*}{$\begin{array}{c}\mathrm{Rb} \\
\mathrm{XRF}\end{array}$} \\
\hline & & & & & & & XRF & NAA & XRF & NAA & & \\
\hline $456 \mathrm{~A}-12-1,62-64$ & 36 & 7380 & 292 & 219 & 1224 & 70840 & 30 & & 54 & & 47 & 742 \\
\hline $456 \mathrm{~A}-14-1,25-27$ & 34 & 6900 & 247 & 272 & 1166 & 62370 & 40 & 34 & 84 & $\begin{array}{l}65 \\
85\end{array}$ & 50 & 6.13 \\
\hline $456-16-2,98-100$ & 30 & 7140 & 290 & 233 & 2246 & 71120 & 37 & 33 & 74 & 72 & 86 & 0 \\
\hline $456-18-1,25-27$ & 32 & 7260 & 257 & 335 & 1286 & 66640 & 34 & 35 & 71 & 73 & 56 & 7.13 \\
\hline $456-19-1,12-15$ & 33 & 6840 & 285 & 314 & 914 & 68880 & 29 & 29 & 44 & 57 & 89 & 4.46 \\
\hline $\begin{array}{l}\text { Average } \\
\text { Dispersion }\end{array}$ & & $\begin{array}{r}7635 \\
200\end{array}$ & $\begin{array}{r}270 \\
21\end{array}$ & & & & & & & & & \\
\hline
\end{tabular}

Note: $\mathrm{XRF}=\mathrm{X}$-ray fluorescence analysis, NAA $=$ neutron activation analysis. 
Table 12. (Continued).

\begin{tabular}{|c|c|c|c|c|c|c|c|c|c|c|c|c|c|}
\hline $\begin{array}{c}\mathrm{Sr} \\
\text { XRF }\end{array}$ & $\begin{array}{c}\mathrm{Y} \\
\mathrm{XRF}\end{array}$ & $\begin{array}{c}\mathrm{Zr} \\
\mathrm{XRF}\end{array}$ & $\begin{array}{c}\mathrm{Nb} \\
\mathrm{XRF}\end{array}$ & $\begin{array}{c}\mathrm{Sb} \\
\mathrm{NAA}\end{array}$ & $\begin{array}{c}\text { Cs } \\
\text { NAA }\end{array}$ & $\begin{array}{c}\mathrm{Ba} \\
\text { NAA }\end{array}$ & $\begin{array}{c}\mathrm{La} \\
\text { NAA }\end{array}$ & $\begin{array}{c}\mathrm{Ce} \\
\mathrm{NAA}\end{array}$ & $\begin{array}{c}\mathrm{Eu} \\
\text { NAA }\end{array}$ & $\begin{array}{c}\mathrm{Tb} \\
\text { NAA }\end{array}$ & $\begin{array}{c}\mathrm{Hf} \\
\text { NAA }\end{array}$ & $\begin{array}{c}\text { Ta } \\
\text { NAA }\end{array}$ & $\begin{array}{c}\mathrm{Tb} \\
\text { NAA }\end{array}$ \\
\hline 316 & 2.44 & 814 & 1.29 & 0.02 & & 21 & 0.22 & 0.3 & 0.16 & 0.03 & 0.11 & & 0.37 \\
\hline 286 & 3.28 & 6.34 & 0 & 0.88 & 0.02 & 12 & 0.11 & 0.26 & 0.11 & 0.09 & 0.09 & & 0.09 \\
\hline 273 & 3.13 & 6.93 & 0.49 & 0.64 & & 34 & 0.23 & & 0.13 & 0.06 & 0.15 & & 0.13 \\
\hline 438 & 0.36 & 8.90 & 0.51 & 2.02 & 0.01 & 230 & 0.54 & 0.6 & 0.08 & 0.02 & 0.05 & & 0.31 \\
\hline
\end{tabular}

Table 13. (Continued).

\begin{tabular}{|c|c|c|c|c|c|c|c|c|c|c|c|c|c|}
\hline $\begin{array}{c}\mathrm{Y} \\
\mathrm{XRF}\end{array}$ & $\begin{array}{c}\mathrm{Zr} \\
\mathrm{XRF}\end{array}$ & $\begin{array}{c}\mathrm{Nb} \\
\mathrm{XRF}\end{array}$ & $\begin{array}{c}\mathrm{Sb} \\
\text { NAA }\end{array}$ & $\begin{array}{c}\text { Cs } \\
\text { NAA }\end{array}$ & $\begin{array}{c}\mathrm{Ba} \\
\text { NAA }\end{array}$ & $\begin{array}{c}\text { La } \\
\text { NAA }\end{array}$ & $\begin{array}{c}\mathrm{Ce} \\
\text { NAA }\end{array}$ & $\begin{array}{c}\text { Eu } \\
\text { NAA }\end{array}$ & $\begin{array}{c}\text { Tb } \\
\text { NAA }\end{array}$ & $\begin{array}{c}\text { Hf } \\
\text { NAA }\end{array}$ & $\begin{array}{c}\text { Ta } \\
\text { NAA }\end{array}$ & $\begin{array}{c}\text { Th } \\
\text { NAA }\end{array}$ & $\begin{array}{c}\text { U } \\
\text { NAA }\end{array}$ \\
\hline 29 & 70 & 3.09 & 0.56 & 0.24 & 27 & 2.65 & 7.4 & 0.99 & 0.51 & 1.63 & 0.13 & 0.45 & 0.19 \\
\hline 25 & 58 & 3.73 & 0.14 & 0.02 & 31 & 2.50 & 6.0 & 0.93 & 0.47 & 1.45 & 0.11 & 0.31 & 0.66 \\
\hline 22 & 54 & 2.53 & 0.18 & 0.02 & 28 & 2.33 & 4.8 & 0.86 & 0.44 & 1.45 & 0.11 & 0.51 & 0.09 \\
\hline 26 & 60 & 2.38 & 0.66 & 0.02 & 27 & 3.6 & 6.9 & 1.04 & 0.48 & 1.52 & 0.12 & 0.36 & 0.1 \\
\hline 24 & 63 & 4 & 0.21 & 0.05 & 31 & 3.2 & 6.8 & 0.87 & 0.48 & 1.5 & 0.12 & 0.43 & 0.07 \\
\hline 28 & 70 & 4.59 & 0.83 & 0.04 & 19 & 3.81 & 8.9 & 1.12 & 0.5 & 1.78 & 0.15 & 0.42 & 0.16 \\
\hline 27 & 68 & 3.44 & 0.03 & & & 3.83 & 5.6 & 1.02 & 0.5 & 1.59 & 0.14 & 0.74 & 0.15 \\
\hline 29 & 77 & 4.25 & & & & & & & & & & & \\
\hline 29 & 76 & 3.62 & 0.11 & 0.06 & 38 & 2.50 & 8.0 & 0.94 & 0.61 & 1.62 & 0.15 & 0.42 & 0.13 \\
\hline 33 & 85 & 3.47 & 0.06 & 0.08 & 20 & 3.5 & 8.3 & 1.21 & 0.63 & 2.2 & 0.17 & 0.40 & 0.11 \\
\hline 31 & 82 & 4.59 & 0.05 & 0.03 & 25 & 3.51 & 9.3 & 1.01 & 0.59 & 2.02 & 0.16 & 0.39 & 0.10 \\
\hline $\begin{array}{l}27.4 \\
\pm 3\end{array}$ & $\begin{array}{l}68.6 \\
10\end{array}$ & $\begin{array}{r}3.54 \\
+0.75\end{array}$ & & & & 3.14 & 7.2 & 1.00 & 0.52 & 1.68 & 0.14 & 0.41 & \\
\hline
\end{tabular}

Table 14. (Continued).

\begin{tabular}{|c|c|c|c|c|c|c|c|c|c|c|c|c|c|c|}
\hline$\underset{\text { XRF }}{\mathrm{Sr}}$ & $\begin{array}{c}\mathrm{Y} \\
\mathrm{XRF}\end{array}$ & $\begin{array}{c}\mathrm{Zr} \\
\mathrm{XRF}\end{array}$ & $\begin{array}{c}\mathrm{Nb} \\
\text { XRF }\end{array}$ & $\begin{array}{c}\mathrm{Sb} \\
\mathrm{NAA}\end{array}$ & $\begin{array}{c}\text { Cs } \\
\text { NAA }\end{array}$ & $\begin{array}{c}\mathrm{Ba} \\
\text { NAA }\end{array}$ & $\begin{array}{c}\text { La } \\
\text { NAA }\end{array}$ & $\begin{array}{c}\mathrm{Ce} \\
\mathrm{NAA}\end{array}$ & $\begin{array}{c}\mathrm{Eu} \\
\mathrm{NAA}\end{array}$ & $\begin{array}{c}\text { Tb } \\
\text { NAA }\end{array}$ & $\begin{array}{c}\text { Hf } \\
\text { NAA }\end{array}$ & $\begin{array}{c}\text { Ta } \\
\text { NAA }\end{array}$ & $\begin{array}{c}\text { Th } \\
\text { NAA }\end{array}$ & $\begin{array}{c}\text { U } \\
\text { NAA }\end{array}$ \\
\hline 232 & 30 & 72 & 3.55 & 0.08 & 0.17 & 51 & 5.05 & 11.8 & 1.23 & 0.66 & 1.94 & 0.16 & 0.69 & 0.13 \\
\hline 174 & 25 & 93 & 3.91 & 0.06 & 0.21 & 13.5 & 2.99 & 9.6 & 1.16 & 0.60 & 2.08 & 0.19 & 0.29 & \\
\hline 146 & 31 & 80 & 347 & 0.07 & 0.02 & 13 & 2.83 & 7.6 & 0.98 & 0.56 & 1.82 & 0.15 & 0.21 & 0.05 \\
\hline 179 & 21 & 86 & 4.50 & 0.07 & 0.33 & 8 & 2.99 & 9.6 & 1.08 & 0.58 & 2.02 & 0.17 & 0.22 & \\
\hline \multirow[t]{3}{*}{172} & 36 & 87 & 3.84 & 0.09 & 0.20 & 11 & 3.39 & 8.4 & 1.15 & 0.66 & 2.01 & 0.16 & 0.30 & 0.13 \\
\hline & 28.2 & 86.5 & 3.93 & & & & 3.05 & 8.8 & 1.09 & 0.60 & 1.98 & 0.17 & 0.26 & \\
\hline & \pm 6 & \pm 5 & 0.43 & & & & 0.24 & 1 & 0.08 & 0.04 & 0.11 & 0.02 & 0.05 & \\
\hline
\end{tabular}


Table 15. Hole 458: Trace elements (ppm).

\begin{tabular}{|c|c|c|c|c|c|c|c|c|c|c|c|c|}
\hline \multirow{2}{*}{$\begin{array}{c}\text { Sample } \\
\text { (interval in } \mathrm{cm} \text { ) }\end{array}$} & \multirow{2}{*}{$\begin{array}{c}\mathrm{Sc} \\
\mathrm{NAA}\end{array}$} & \multirow{2}{*}{$\begin{array}{c}\mathrm{Ti} \\
\text { XRF }\end{array}$} & \multirow{2}{*}{$\begin{array}{l}\mathrm{V} \\
\mathrm{XRF}\end{array}$} & \multirow{2}{*}{$\begin{array}{l}\mathrm{Cr} \\
\mathrm{XRF}\end{array}$} & \multirow{2}{*}{$\begin{array}{l}\text { Mn } \\
\text { XRF }\end{array}$} & \multirow{2}{*}{$\begin{array}{c}\mathrm{Fe} \\
\mathrm{XRF}\end{array}$} & \multicolumn{2}{|c|}{$\mathrm{Co}$} & \multicolumn{2}{|c|}{$\mathrm{Ni}$} & \multirow{2}{*}{$\underset{\mathrm{XRF}}{\mathrm{Zn}}$} & \multirow{2}{*}{$\begin{array}{c}\mathrm{Rb} \\
\mathrm{XRF}\end{array}$} \\
\hline & & & & & & & $\mathrm{XRF}$ & NAA & $\mathrm{XRF}$ & NAA & & \\
\hline $458-28-1,102-104$ & & 1920 & 246 & 250 & 1069 & 62230 & 33 & & 72 & & 67 & 6.05 \\
\hline \multirow[t]{2}{*}{$458-29-2,51-54$} & 35 & 1920 & 243 & 227 & 914 & 64820 & 43 & \multirow{3}{*}{43} & 68 & \multirow[b]{2}{*}{73} & 70 & 7.38 \\
\hline & & & & & & & & & & & & 6.5 \\
\hline \multirow[t]{2}{*}{$458-30-2,32-35$} & 34 & 1920 & 196 & 238 & 906 & 63770 & 37 & & 77 & & 69 & 10.88 \\
\hline & & & & & & & & \multirow[t]{2}{*}{36} & & \multirow[t]{2}{*}{74} & & 9.1 \\
\hline \multirow[t]{2}{*}{$458-32-3,110-112$} & 32 & 1620 & 195 & 204 & 867 & 59080 & 31 & & 57 & & 35 & 65.16 \\
\hline & & & & & & & & 33 & & 65 & & 58 \\
\hline $458-33-2,115-117$ & 34 & 1740 & 260 & 250 & 929 & 57960 & 35 & \multirow[t]{2}{*}{38} & 77 & \multirow[t]{4}{*}{76} & 39 & 15.59 \\
\hline $458-35-2,95-98$ & & 2040 & 224 & 279 & 813 & 62300 & 27 & & 74 & & 49 & 24.70 \\
\hline $458-37-2,31-35$ & & 1800 & 228 & 257 & 852 & 61460 & 35 & & 64 & & 42 & 33.36 \\
\hline \multirow[t]{2}{*}{$458-36-3,24-27$} & 32 & 2100 & 302 & 286 & 720 & 68320 & 33 & \multirow{3}{*}{3} & 71 & & 74 & 19.82 \\
\hline & & & & & & & & & & \multirow{2}{*}{81} & & 17.3 \\
\hline $458-40-1,116-118$ & 30 & 2040 & 199 & 276 & 837 & 71120 & 39 & & 92 & & 86 & 14,86 \\
\hline Average & & 1900 & 232 & & & & & & & & & \\
\hline Dispersion & & 156 & 35 & & & & & & & & & \\
\hline $458-41-1,60-63$ & 24 & 6300 & 265 & 233 & 674 & 69860 & 18 & \multirow[b]{2}{*}{18} & 14 & \multirow[b]{2}{*}{10} & 104 & 48.56 \\
\hline $458-43-1,88-92$ & & 3300 & 307 & 257 & 650 & 71400 & 25 & & 73 & & 78 & 20.04 \\
\hline \multirow[t]{2}{*}{$458-44-1,54-58$} & 30 & 3000 & 281 & 182 & 1268 & 72380 & 40 & & 72 & & 66 & 8.73 \\
\hline & & & & & & & & 39.5 & & 77 & & 7.1 \\
\hline $458-47-1,56-59$ & 30 & 6060 & 428 & 13.17 & 852 & 94290 & 47 & & 32 & & 103 & 8.50 \\
\hline & & & & & & & & 45 & & 22 & & \\
\hline $458-47-2,34-37$ & 28 & 5520 & 399 & 12.13 & 697 & 91840 & 38 & & 40 & & 101 & 11.84 \\
\hline $458-48-1 \quad 41-43$ & 30 & 5880 & 531 & 2061 & 770 & 04780 & 42 & 34 & 3 & 22 & 113 & 10.51 \\
\hline $450-40-1,41-43$ & 30 & 2000 & 221 & 20.01 & 720 & 34100 & 42 & 38 & 34 & 30 & 130 & 9.1 \\
\hline
\end{tabular}

Note: $\mathrm{XRF}=\mathrm{X}$-ray fluorescence analysis, NAA $=$ neutron activation analysis.

Table 16. Hole 459B: Trace elements (ppm).

\begin{tabular}{|c|c|c|c|c|c|c|c|c|c|c|c|c|}
\hline \multirow{2}{*}{$\begin{array}{c}\text { Sample } \\
\text { (interval in } \mathrm{cm} \text { ) }\end{array}$} & \multirow{2}{*}{$\begin{array}{c}\mathrm{Sc} \\
\mathrm{NAA}\end{array}$} & \multirow{2}{*}{$\begin{array}{c}\mathrm{Ti} \\
\text { XRF }\end{array}$} & \multirow{2}{*}{$\begin{array}{l}\mathrm{V} \\
\mathrm{XRF}\end{array}$} & \multirow{2}{*}{$\begin{array}{c}\mathrm{Cr} \\
\mathrm{XRF}\end{array}$} & \multirow{2}{*}{$\begin{array}{l}\text { Mn } \\
\text { XRF }\end{array}$} & \multirow{2}{*}{$\begin{array}{c}\mathrm{Fe} \\
\mathrm{XRF}\end{array}$} & \multicolumn{2}{|c|}{ Co } & \multicolumn{2}{|c|}{$\mathrm{Ni}$} & \multirow{2}{*}{$\underset{\mathrm{XRF}}{\mathrm{Zn}}$} & \multirow{2}{*}{$\begin{array}{c}\mathrm{Rb} \\
\mathrm{XRF}\end{array}$} \\
\hline & & & & & & & XRF & $\overline{\text { NAA }}$ & XRF & $\overline{\mathrm{NAA}}$ & & \\
\hline 459B-60-1, 48-51 & 39 & 4440 & 372 & 299 & 914 & 78750 & 29 & & 40 & & 86 & 5.65 \\
\hline $459 \mathrm{~B}-60-2,37-90$ & 36 & 4020 & 318 & 152 & 1053 & 71400 & 39 & 30 & 49 & 55 & 55 & 27.57 \\
\hline $459 \mathrm{~B}-61-2,12-16$ & 35 & 4200 & 351 & 158 & 1139 & 72450 & 38 & 43 & 47 & 53 & 59 & 10.30 \\
\hline 459B-66-2, 92-95 & 35 & 6420 & 419 & 9.59 & 1286 & 88270 & 40 & 41.6 & 22 & 24 & 76 & 13.94 \\
\hline 459B-69-1, 81-84 & 28 & 4680 & 317 & 33.39 & 852 & 68460 & 28 & 29 & 26 & 26 & 53 & 6.17 \\
\hline 458B-72-1, 94-97 & 28 & 6120 & 424 & 14.06 & 875 & 84210 & 34 & 32 & 35 & 18 & 60 & 36.82 \\
\hline 459B-73-2, 13-17 & 26 & 6300 & 329 & 6.20 & 929 & 86590 & 33 & 31 & 24 & 18 & 114 & 3.67 \\
\hline
\end{tabular}

Note: $\mathrm{XRF}=\mathrm{X}$-ray fluorescence analysis, $\mathrm{NAA}=$ neutron activation analysis.

Table 17. Rare earth abundances (ppm) chosen for normalization.

\begin{tabular}{lcccccccccc}
\hline $\mathrm{Th}^{\mathrm{a}}$ & $\mathrm{Ta}^{\mathrm{a}}$ & $\mathrm{La}$ & $\mathrm{Nb}^{\mathrm{a}}$ & $\mathrm{Ce}$ & $\mathrm{Pr}$ & $\mathrm{Nd}$ & $\mathrm{Zr}^{\mathrm{a}}$ & $\mathrm{Hf}^{\mathrm{a}}$ & $\mathrm{Sm}$ & $\mathrm{Ti}^{\mathrm{a}}$ \\
\hline 0.028 & 0.031 & 0.315 & 0.53 & 0.81 & 0.112 & 0.60 & 5.13 & 0.128 & 0.19 & 460 \\
\hline $\mathrm{Eu}$ & $\mathrm{Gd}$ & $\mathrm{Tb}$ & $\mathrm{Y}^{\mathrm{a}}$ & $\mathrm{Dy}$ & $\mathrm{Ho}$ & $\mathrm{Er}$ & $\mathrm{Tm}$ & $\mathrm{Yb}$ & $\mathrm{Lu}$ & $\mathrm{V}^{\mathrm{a}}$ \\
\hline 0.072 & 0.26 & 0.047 & 2.16 & 0.32 & 0.07 & 0.21 & 0.03 & 0.2 & 0.032 & 22 \\
\hline \multicolumn{2}{l}{ Computed values. }
\end{tabular}


Table 15. (Continued).

\begin{tabular}{|c|c|c|c|c|c|c|c|c|c|c|c|c|c|c|}
\hline$\underset{\mathrm{XRF}}{\mathrm{Sr}}$ & $\begin{array}{c}\mathrm{Y} \\
\mathrm{XRF}\end{array}$ & $\underset{\mathrm{XRF}}{\mathrm{Zr}}$ & $\begin{array}{c}\mathrm{Nb} \\
\mathrm{XRF}\end{array}$ & $\begin{array}{c}\mathrm{Sb} \\
\text { NAA }\end{array}$ & $\begin{array}{c}\mathrm{Cs} \\
\text { NAA }\end{array}$ & $\begin{array}{c}\mathrm{Ba} \\
\mathrm{NAA}\end{array}$ & $\begin{array}{c}\mathrm{La} \\
\mathrm{NAA}\end{array}$ & $\begin{array}{c}\mathrm{Ce} \\
\mathrm{NAA}\end{array}$ & $\begin{array}{c}\text { Eu } \\
\text { NAA }\end{array}$ & $\begin{array}{c}\text { Tb } \\
\text { NAA }\end{array}$ & $\begin{array}{c}\text { Tb } \\
\text { NAA }\end{array}$ & $\begin{array}{c}\mathrm{Ta} \\
\text { NAA }\end{array}$ & $\begin{array}{c}\text { Th } \\
\text { NAA }\end{array}$ & $\begin{array}{c}\text { U } \\
\text { NAA }\end{array}$ \\
\hline 100 & 6.96 & 35 & 1.60 & & & & & & & & & & & \\
\hline 98 & 4.56 & 35 & 1.33 & 0.12 & 0.06 & 16 & 0.50 & 1.3 & 0.28 & 0.11 & 0.81 & 0.05 & 0.13 & \\
\hline 93 & 5.73 & 37 & 1.96 & 0.07 & 0.06 & 12 & 0.63 & & 0.18 & 0.10 & 0.74 & 0.05 & 0.14 & \\
\hline 95 & 8.74 & 30 & 1.45 & 0.12 & 1.02 & 36 & 0.80 & & 0.26 & 0.16 & 0.80 & 0.04 & 0.11 & \\
\hline 96 & 9.32 & 32 & 1.04 & 0.08 & 0.19 & 22 & 0.9 & 1.4 & 0.25 & 0.16 & 0.8 & 0.05 & 0.19 & 2 \\
\hline $\begin{array}{l}121 \\
1.5\end{array}$ & $\begin{array}{r}9.46 \\
12.18\end{array}$ & $\begin{array}{l}38 \\
33\end{array}$ & $\begin{array}{l}2.20 \\
2.25\end{array}$ & & & & & & & & & & & \\
\hline 109 & 8.11 & 37 & 2.48 & 0.13 & 0.21 & 15 & 0.58 & 2.0 & 0.29 & 0.18 & 0.86 & 0.06 & 0.15 & 0.1 \\
\hline 101 & 5.55 & 37 & 2.18 & 0.15 & 0.21 & 16 & 0.52 & 2.0 & 0.20 & 0.09 & 0.80 & 0.06 & 0.13 & 0.16 \\
\hline & 7.3 & 35 & 1.83 & & & & 0.66 & 1.68 & 0.24 & 0.13 & 0.80 & 0.05 & 0.14 & \\
\hline & 2.0 & 3 & 0.5 & & & & 0.16 & 0.4 & 0.04 & 0.04 & 0.04 & 0.01 & 0.03 & \\
\hline 159 & 45.79 & 92 & 4.28 & 0.16 & 1.03 & 42 & 3.68 & 9.5 & 1.07 & 0.70 & 2.63 & 0.14 & 0.26 & \\
\hline 141 & 23.86 & 53 & 2.80 & & & & & & & & & & & \\
\hline 90 & 12.59 & 45 & 0.72 & 0.08 & 0.23 & 16 & 0.76 & 1.6 & 0.28 & 0.19 & 1.03 & 0.05 & 0.23 & \\
\hline 143 & 30 & 73 & 3.25 & 0.11 & 0.13 & 14 & 2.15 & 6.1 & 0.80 & 0.51 & 1.72 & 0.09 & 0.23 & \\
\hline 134 & 16 & 61 & 1.97 & 0.18 & 0.22 & & 1.57 & & 0.61 & 0.29 & 1.56 & 0.08 & 0.20 & 0.19 \\
\hline 136 & 40 & 60 & 3.86 & 0.13 & 0.14 & & 2.26 & 6.1 & 0.91 & 0.60 & 1.44 & 0.08 & 0.22 & 0.10 \\
\hline
\end{tabular}

Table 16. (Continued).

\begin{tabular}{|c|c|c|c|c|c|c|c|c|c|c|c|c|c|c|}
\hline $\begin{array}{c}\mathrm{Sr} \\
\mathrm{XRF}\end{array}$ & $\begin{array}{c}\mathrm{Y} \\
\mathrm{XRF}\end{array}$ & $\begin{array}{c}\mathrm{Zr} \\
\mathrm{XRF}\end{array}$ & $\begin{array}{c}\mathrm{Nb} \\
\mathrm{XRF}\end{array}$ & $\begin{array}{c}\mathrm{Sb} \\
\mathrm{NAA}\end{array}$ & $\begin{array}{c}\text { Cs } \\
\text { NAA }\end{array}$ & $\begin{array}{c}\mathrm{Ba} \\
\text { NAA }\end{array}$ & $\begin{array}{c}\mathrm{La} \\
\mathrm{NAA}\end{array}$ & $\begin{array}{c}\mathrm{Ce} \\
\mathrm{NAA}\end{array}$ & $\begin{array}{c}\text { Eu } \\
\text { NAA }\end{array}$ & $\begin{array}{c}\mathrm{Tb} \\
\text { NAA }\end{array}$ & $\begin{array}{l}\text { Hf } \\
\text { NAA }\end{array}$ & $\begin{array}{c}\mathrm{Ta} \\
\text { NAA }\end{array}$ & $\begin{array}{c}\text { Th } \\
\text { NAA }\end{array}$ & $\begin{array}{c}\mathrm{U} \\
\mathrm{NAA}\end{array}$ \\
\hline 124 & 22 & 36 & 2.95 & 0.32 & 0.21 & 8 & 2.06 & 4.6 & 0.69 & 0.43 & 1.16 & 0.07 & 0.14 & 0.09 \\
\hline 26 & 18 & 41 & 2.57 & 0.04 & 2.8 & 16 & 1.20 & 2.8 & 0.61 & 0.36 & 1.04 & 0.05 & 0.11 & 0.09 \\
\hline 113 & 19 & 40 & 2.12 & 0.03 & 0.40 & & 1.40 & 3.5 & 0.70 & 0.31 & 1.10 & 0.05 & 0.18 & 0.10 \\
\hline 120 & 31 & 62 & 3.60 & 0.05 & 0.39 & 8 & 1.88 & 4.2 & 0.85 & 0.58 & 1.82 & 0.07 & 0.19 & 0.18 \\
\hline 142 & 27 & 57 & 2.26 & 0.12 & 0.05 & 15 & 0.98 & 5.7 & 0.64 & 0.48 & 1.63 & 0.06 & 0.28 & 0.14 \\
\hline 123 & 30 & 67 & 3.69 & 0.08 & 1.06 & 19 & 2.34 & 6.4 & 0.85 & 0.51 & 1.75 & 0.07 & 0.21 & \\
\hline 148 & 45 & 82 & 3.86 & 0.10 & 0.11 & & 3.41 & 8.8 & 1.02 & 0.74 & 2.22 & 0.09 & 0.29 & 0.14 \\
\hline
\end{tabular}

